PNL-10377

UC-400

\title{
Re-Analysis of Hydraulic Tests Conducted for Well 4A
}

\author{
F. A. Spane
}

January 1995

Prepared for

Westinghouse Hanford Company and the U.S. Department of Energy under Contract DE-AC06-76RLO 1830

Pacific Northwest Laboratory

Richland, Washington 99352 


\section{DISCLAIMER}

This report was prepared as an account of work sponsored by an agency of the United States Government. Neither the United States Government nor any agency thereof, nor any of their employees, make any warranty, express or implied, or assumes any legal liability or responsibility for the accuracy, completeness, or usefulness of any information, apparatus, product, or process disclosed, or represents that its use would not infringe privately owned rights. Reference herein to any specific commercial product, process, or service by trade name, trademark, manufacturer, or otherwise does not necessarily constitute or imply its endorsement, recommendation, or favoring by the United States Government or any agency thereof. The views and opinions of authors expressed herein do not necessarily state or reflect those of the United States Government or any agency thereof. 


\section{DISCLAIMER}

Portions of this document may be illegible in electronic image products. Images are produced from the best available original document. 
March 17, 1994

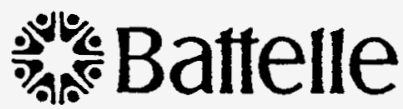

Pacific Nortinwest Laboratories Zattelle 3oulera:d ?.O. 30x 0.99

R:chland. W ashingion 59352

Teiephone (509) 376-8329

Mr. Craig Swanson

Westinghouse Hanford Company

740 Stevens

MSIN H6-OG

Richland, Washington 99352

SUBJECT: Final Draft: Re-Analysis of Pumping and Slug Interference Tests at Wells $4 \mathrm{~A}-4 T$

Dear Craig: .

The following represents the final draft of a letter report that provides a re-analysis of the constant-rate pumping test and siug interference test conducted at wells $4 \mathrm{~A}-4 \mathrm{~T}$. The re-analysis includes the effects of wellbore storage, partial penetration, and vertical anisotropy. The re-analysis demonstrates that comparable results were obtained from both the pumping and slug interference characterization tests.

Sincerely,

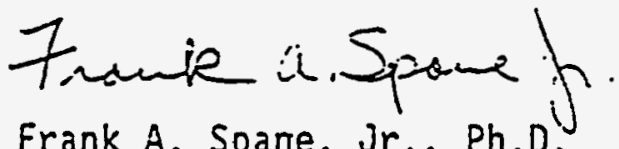

Frank A. Spane, Jr., Ph.D.

Staff Scientist

Hydrologic and Geochemical Characterization

Earth and Environmental Sciences Center

\section{FAS/}

Attachments

cc: RW Bryce

PD Thorne

DL Stewart

VR Vermeul

DR Newcomer 
Mr. Craig Swanson

March 17, 1994

Page 3

\subsection{PUMPING TEST RE-ANALYSIS}

The re-analysis procedure for the pumping test drawdown phase observed at well $4 \mathrm{~A}$ included the following analys is elements:

- an initial diagnostic drawdown derivative analysis,

- a late-time, Neuman Type B curve analysis, and

- a complete unconfined aquifer type-curve analysis, including wellbore storage effects.

\subsection{Diagnostic Analysis}

Combined drawdown and drawdown derivative plots have been shown to be a powerful diagnostic tool in identifying operative flow conditions and factors influencing drawdown during constant discharge pumping tests (e.g., Bourdet et a]. 1983, 1989, Spane 1993). Figure 1 shows the combined drawdown and drawdown derivative plot for observation well $4 \mathrm{~A}$. The drawdown derivatives were calculated using the DERIV program described in Spane and Wurstner (1993). Based on a diagnostic analysis of the pattern exhibited in Figure 1, the following operative flow conditions during the test were interpreted:

- Combined wellbore storage and delayed-yield response conditions during the early phases of the test (i.e., up to $\approx 4 \mathrm{~min}$ )

- unconfined aquifer, Type B curve response characteristics between 4 and 500 min

variable drawdown/derivative pattern after $500 \mathrm{~min}$, most likely attributable to discharge fluctuations.

\subsection{Type B Curve Analysis}

To provide an initial estimate of transmissivity and specific yield, drawdown data during the test period indicative of Neuman unconfined aquifer, Type $B$ curve behavior was analyzed (i.e., for test times $\geq 4 \mathrm{~min}$ ). The combined Type $B$ drawdown and drawdown derivative plot matching procedure described in Spane (1993) was used in the test analysis. Drawdown type curves were generated using the WTAQI program described by Moench (1993). As discussed in Moench (1993), the WTAQl program runs faster and does not exhibit some of the test instabilities that are sometimes exhibited with the DELAY2 program 
Mr. Craig Swanson

March 17, 1994

Page 5.

where

$$
\begin{aligned}
r_{e}= & \text { radius of the well screen } \\
r_{w}= & \text { radial distance from center of well to } \\
& \text { the outside sand/gravel pack } \\
n= & \text { porosity of the sand/gravel pack }
\end{aligned}
$$

For well 4A, given a well screen radius of $0.051 \mathrm{~m}(0.1667 \mathrm{ft})$, a radial gravel pack distance of $0.102 \mathrm{~m}(0.333 \mathrm{ft})$, and an assume porosity of 30 percent, yields a $r_{\text {ew }}$ for well $4 \mathrm{~A}$ of $0.070 \mathrm{~m}(0.230 \mathrm{ft})$.

A calculation of the $r_{\text {ex }}$ for the pumped well (well 4T), however, is more difficult because of the "natural" sand/gravel pack that was developed around the well, during previous wellbore developmental pumping. As noted-in Swanson (1992) several barrels of sand and silt were removed from well $4 T$ during the developmental pumping phase. The presence of an extensive zone of "enhanced" permeability surrounding the immediate wellbore is indicated also by the bilinear response exhibited at well $4 T$ during the slug test (see Figure 3 ). As a means of estimating possible values for the $r$ for well $4 \mathrm{~T}$, the radial distance, $r$, to the outside boundary of the developed "natural" sand/gravel pack calculated based on the known displacement, $V_{t}=0.027 \mathrm{~m}^{3}\left(0.96 \mathrm{ft}^{3}\right)$ and initial stress response, $H_{0}=0.168 \mathrm{~m}(0.55 \mathrm{ft})$ observed at wel1 $4 \mathrm{~T}$ during the April 14, 1992 siug test (see Figure 3). For this calculation, the following relationships were developed:

$$
\dot{\vdots} V_{t}=V_{w e}+V_{w a}
$$

where $\quad V_{t}=$ slug test volume displacement; $\left(0.027 \mathrm{~m}^{3}\right)$

$V_{w c}=$ displacement volume within well screen

$V_{\text {wa }}=$ displacement volume within natural sand/ gravel pack zone

where

$$
V_{w c}=\pi r_{c t}^{2} H_{0}=0.0067 \mathrm{~m} ;\left(0.237 \mathrm{ft}^{3}\right)
$$

where $\quad r_{z=}=$ radius of well $4 \mathrm{~T}$ well screen;

Re-arranging Equation 2,

$$
0.113 \mathrm{~m}(0.370 \mathrm{ft})
$$

$$
V_{w a}=V_{t}-V_{w c}=0.020 \mathrm{~m}^{3} ;\left(0.723 \mathrm{ft}^{3}\right)
$$

Also note that from a modification of a relationship in Bouwer (1989) 
Mr. Craig Swanson

March 17, 1994

Page 7

obtained with the Type B curve analysis and to those previously reported by Swanson (1992). It should be noted, however, that the estimate for storativity is considered to be very qualitative; primarily due to the lack of early-time data (i.e., the first $25 \mathrm{~s}$ ), and the 1ack of sensitivity for small drawdown measurements (Note the "stair-stepped" pattern for drawdowns less than $0.015 \mathrm{~m}$ ).

\subsection{SLUG INTERFERENCE TEST RE-ANALYSIS}

As noted in Section 1.0, the original slug interference test analysis was based on the analysis procedure presented in Novakowski (1990), which is dependent on fully penetrating wells within isotropic confined aquifer conditions. Subsequent to this analysis, analytical methods have been developed, which provide the opportunity of extending slug interference analysis to a variety of test conditions including: unconfined aquifers; partially penetrating wells; anisotropic conditions; and wellbore storage effects. The basis of the analysis extension is based on analytical discussions presented in Novakowski (1989), Peres (1989) and Peres et al. (1989), which demonstrate that slug tests can be represented as a speciaijized form of constant-rate pumping tests. As noted in Peres (1989), the slug test wellbore solution can be "... obtained directly from the time derivative of the constant rate wellbore storage solution ... (and that this relationship) is also valid for any reservoir/well system and holds at any position within the reservoir."

A detailed description of the procedures for slug test conversion are not presented in this letter report. The reader should consult the aforementioned references for analytical justification of the slug test conversion method. Briefly stated however, slug test data were converted to equivalent head (pumping test) drawdown data by integrating the observed slug test head data over the observed test time, as indicated in Peres et al. (1989).

Multiplication of the observed siug test head data by the observed test time, yields the logarithmic derivative of the equivalent head change for a constant-rate pumping test.

Figure 6 shows a comparison of the drawdown and drawdown derivative response observed at well $4 \mathrm{~A}$ during the constant-rate pumping test, with the converted equivalent head and head derivative response obtained during the slug interference test. As indicated in the Figure, similar pattern shapes are exhibited. In order to equate the two test responses, however, the stress levels for the two tests need to be normalized.

As noted in Novakowski (1989) and Peres, et al. (1989), the instantaneous discharge rate, $Q_{i},(\mathrm{gpm})$ imposed by a slug test can be calculated directly by the displacement volume, $V$. . For a displacement volume of $0.027 \mathrm{~m}^{3} 10.96$ $\left.\mathrm{ft}^{3}\right), a Q_{i}$ value of $27.2 \mathrm{~L} / \mathrm{min}(7.18 \mathrm{gpm})$ is indicated. To normalize the slug 
Mr. Craig Swanson

March 17, 1994

Page 9

of predictive response shapes are still possible. The number of predictive responses can be greatiy reduced, however, if expected (common) bounds can applied for some of the formation hydraulic properties. Limits used for slug interference type curves generated for the analysis of the well $4 \mathrm{~A}$ test response included: $S_{y}=0.005$ to $0.4 ; S=10^{-4}$ to $10^{-1} ; K_{0}=0.01$ to $1.0 ; T=$ $10^{1}$ to $10^{4} \mathrm{~m}^{2} / \mathrm{d}\left(10^{2}\right.$ to $\left.10^{5} \mathrm{ft}^{2} / \mathrm{d}\right)$.

To examine the sensitivity of the predicted slug interference response to various hydraulic property combinations, individual type curves were generated by systematically varying selected parameter estimates. Figures 8 through 12 show the results of the sensitivity analysis. As expected, variation in the selected hydraulic property va'lues causes significant changes in the shape and amplitude of the predicted slug interference response. The following general observations are provided that summarize the sensitivity of the predicted slug interference response to hydraulic property variation (i.e., given well $4 \mathrm{~A}$ test sitè conditions):

- transmissivity is the principal parameter controlling the transmission (i.e., arrival time) of the interference response (Figure 8)

- storativity exerts a significant influence on the amplitude and shape of the initial slug interference "hump" (Figures 9 and 10)

- wellbore storage effects dampen and delay transmission of the initial slug interference response observed (Figure 10)

- the storativity/specific yield ratio affects primarily the slope of the recessional iimb of the initial slug interference "hump" response (Figure 11 ), and

- vertical anisotropy, like storativity, exerts a significant influence on the amplitude and shape of the initial slug interference response (Figure 12); however, the predominant region of influence is the peak amplitude and recessional limb of the interference response.

\subsection{SUMMARY}

A general procedure is outlined for generation of slug interference test responses within anisotropic, unconfined aquifers with partially penetrating well configurations. The procedure is based on conversion of available unconfined aquifer constant-rate pumping test type curves, which have been modified to account for the affects of pumping well wellbore storage. Results of sensitivity analyses, indicated that variations in $T, S, S_{y}, K_{3}$ exert significant influence (in varying degrees) on the transmissioh, amplitude, and shape of the slug interference response. 
Mr. Craig Swanson

March 17, 1994

Page 11

\section{$\underline{5.0 \quad \text { REFERENCES }}$}

Bourdet, D., T.M. Whittle, A.A. Douglas, and Y.M. Pirard. 1983. "A New Set of Type Curves Simplifies Well Test Analysis. World 0il, May: 95-106.

Bourdet, D., J.A. Ayoub, and Y.M. Pirard. 1989. "Use of Pressure Derivative in Well-Test Interpretation. SPE Formation Evaluation, June 1989: 293-302.

Cooper, H.H., Jr., J.D. Bredehoeft, and I.S. Papadopulos. 1967. "Response of a Finite-Diameter Well to an Instantaneous Charge of Water." Water Resources Research. 3(1): 263-269.

Dawson, K.J. and J.D. Istok. 1991. Aquifer Testing: Design and Analysis of Pumping and Slug Tests. Lewis Publishers, Inc., Chelsea, Michigan.

Earlougher, R.C., Jr. 1977. Advances in Well Test Analysis. Henry L. Doherty Series, Monograph Volume 5, Soc. of Pet. Engineers, AIME.

Fenske, P.R. 1977. "Radial Flow With Discharging-Well and Observation-Well Storage." Journal of Hydrology, 32: 87-96.

Horn, R.N. 1990. Hodern Well Test Analysis: A Computer-Aided Aporoach. Petroway, Inc., Palo Alto, California; distributed by Soc. Pet. Engrs., Richfield, Texas.

Hydralogic. 1989. ISOAOX: Operations Guide. Hydralogic, P.0. Box 4722, Missoula, Montana.

Moench, A.F. 1993. "Computation of Type Curves for Flow to Partially Penetrating Wells in Water-Table Aquifers." Ground Water. 31(6): 966-971.

Neuman, S.P. 1975. "Analysis of Pumping Test Data from Anisotropic Unconfined Aquifers Considering Delayed Gravity Response." Water Resour. Res. $11(2): 329-342$.

Novakowski, K.S. 1989. "Analysis of Pulse Interference Tests." Water Resour. Res., 25(11): 2377-2387.

Novakowski, K.S. 1990. "Analysis of Aquifer Tests Conducted in Fractured Rock: A Review of the Physical Background and the Design of a Computer Program for Generating Type Curves." Ground Water 28(1): 99-105.

Peres, A.M. 1989. Analysis of Slug and Drillistem Tests. unpublished Ph.D. dissertation, University of Tulsa, Tulsa, Oklahoma.

Peres, A.M., M. Onur, and A.C. Reynolds. 1989. "A New Analys is Procedure For. Determining Aquifer Properties From Slug Test Data." Hater Resources

Research. 25(7): 1591-1602. 
Mr. Craig Swanson

March 17, 1994

Page 13

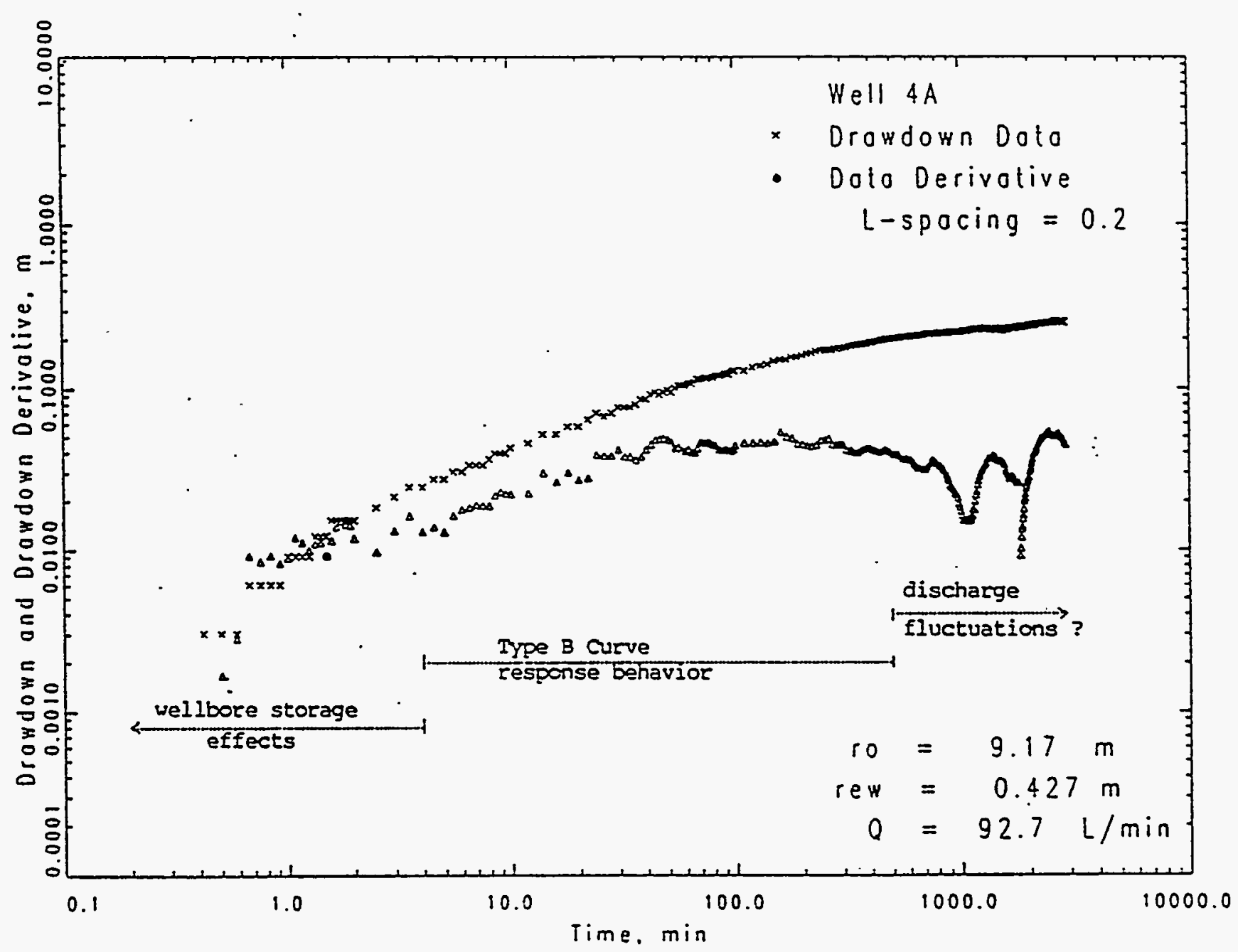

FIGURE 1. Diagnostic Drawdown and Drawdown Derivative Plot For Well 4A. 
Mr. Craig Swanson

March 17, 1994

Page 15

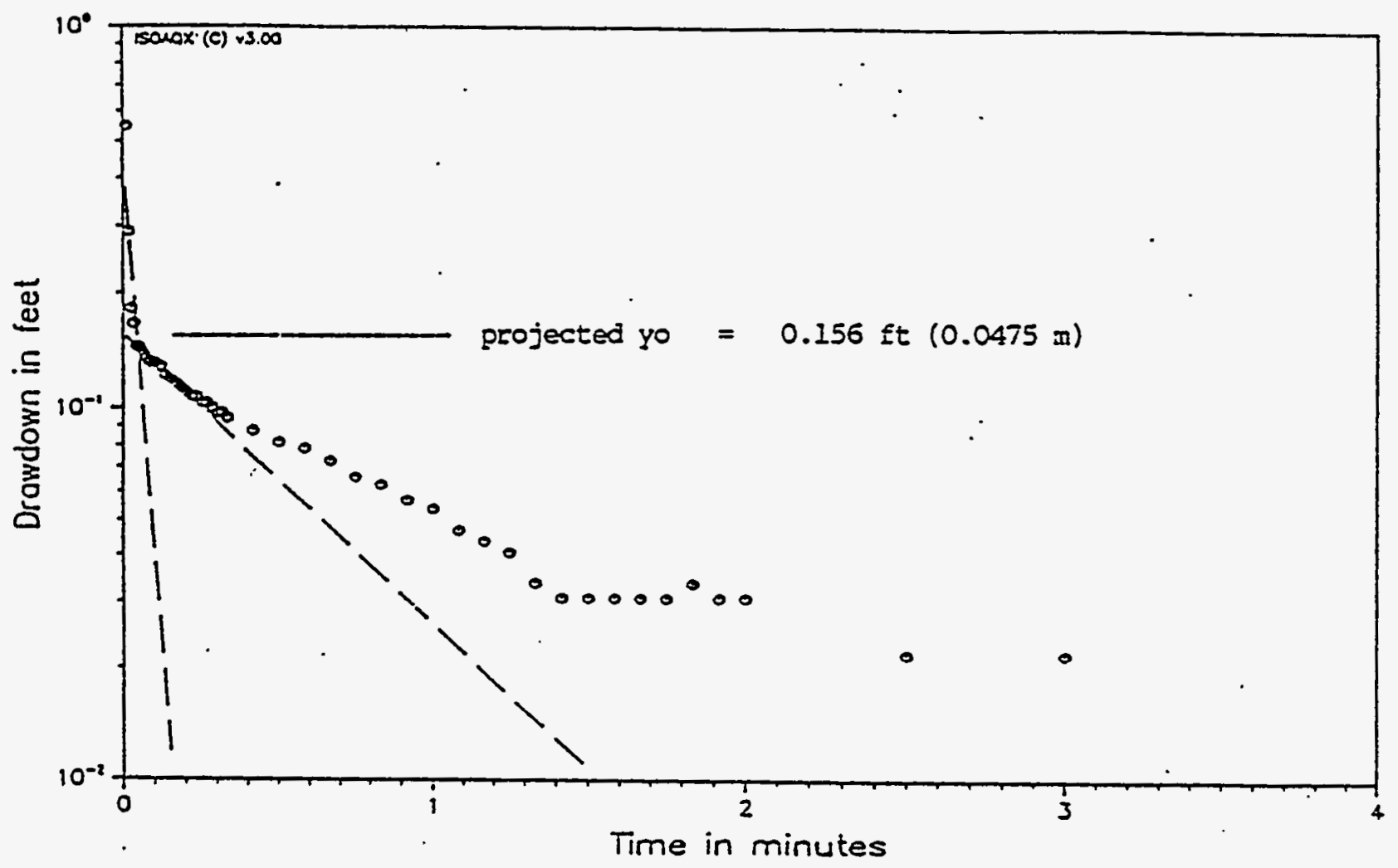

FIGURE 3. Slug Test Response At Well 4T; Test Date: ApriT 14, 1992. (adapted from Swanson 1992) 
Mr. Craig Swanson

March 17, 1994

Page 17

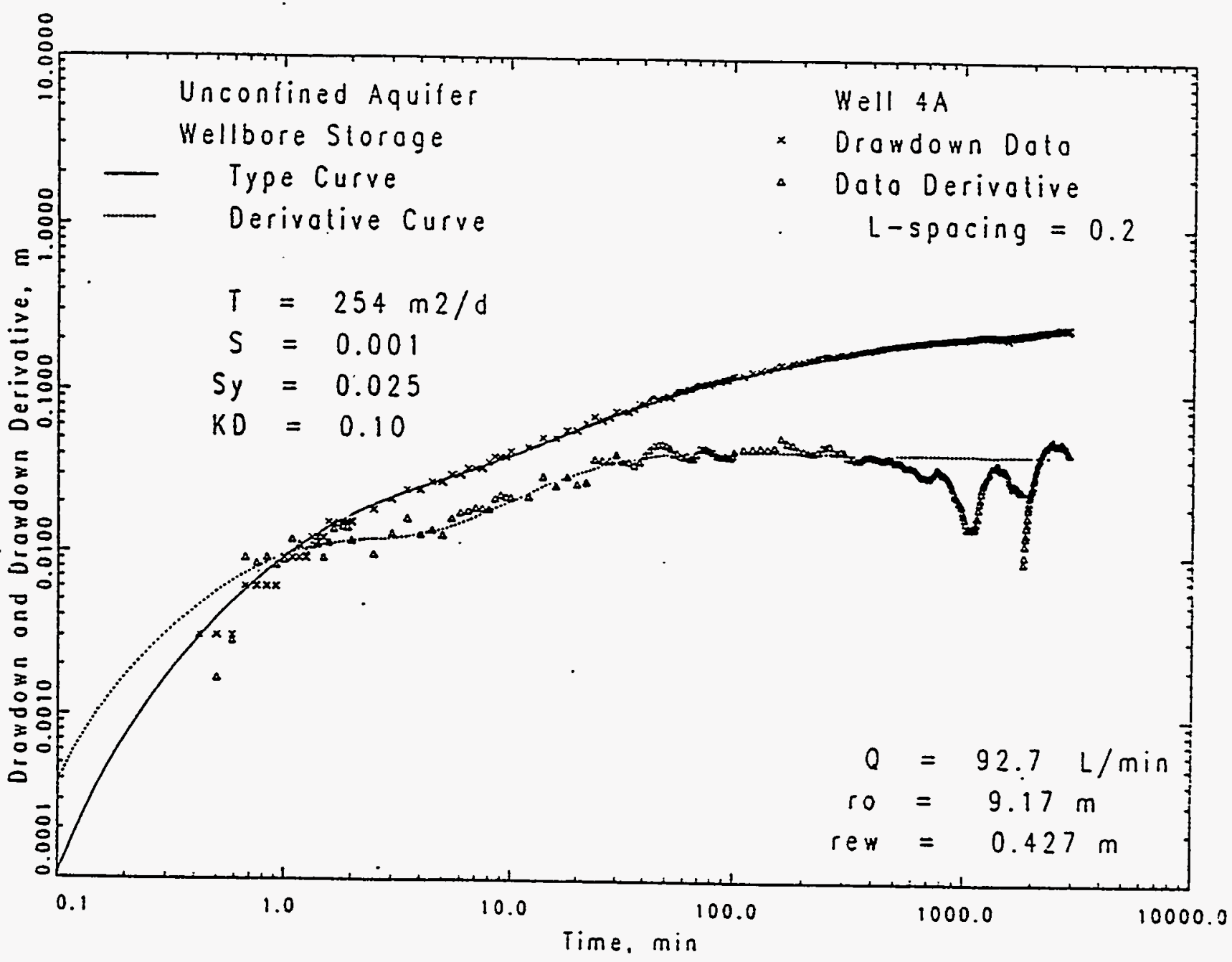

FIGURE 5. Combined Drawdown and Drawdown Derivative, Complete Unconfined Aquifer Type-Curve Analysis For Well 4A. 
Mr. Craig Swanson

March 17, 1994

Page 19

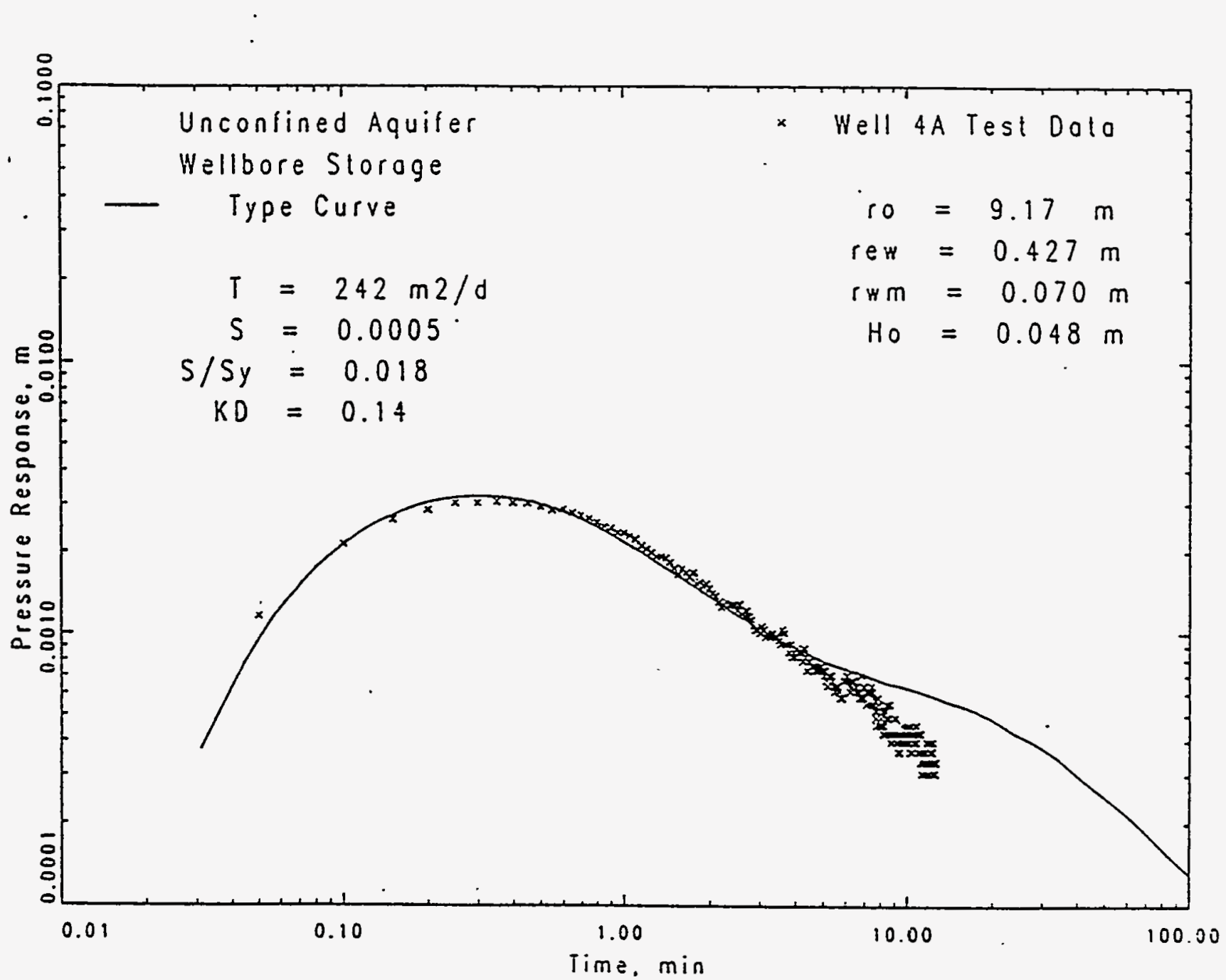

FIGURE 7. Unconfined Aquifer Type-Curve Analysis For Slug Interference Test Response For Well 4A. 
Mr. Craig Swanson

March 17, 1994

Page 21

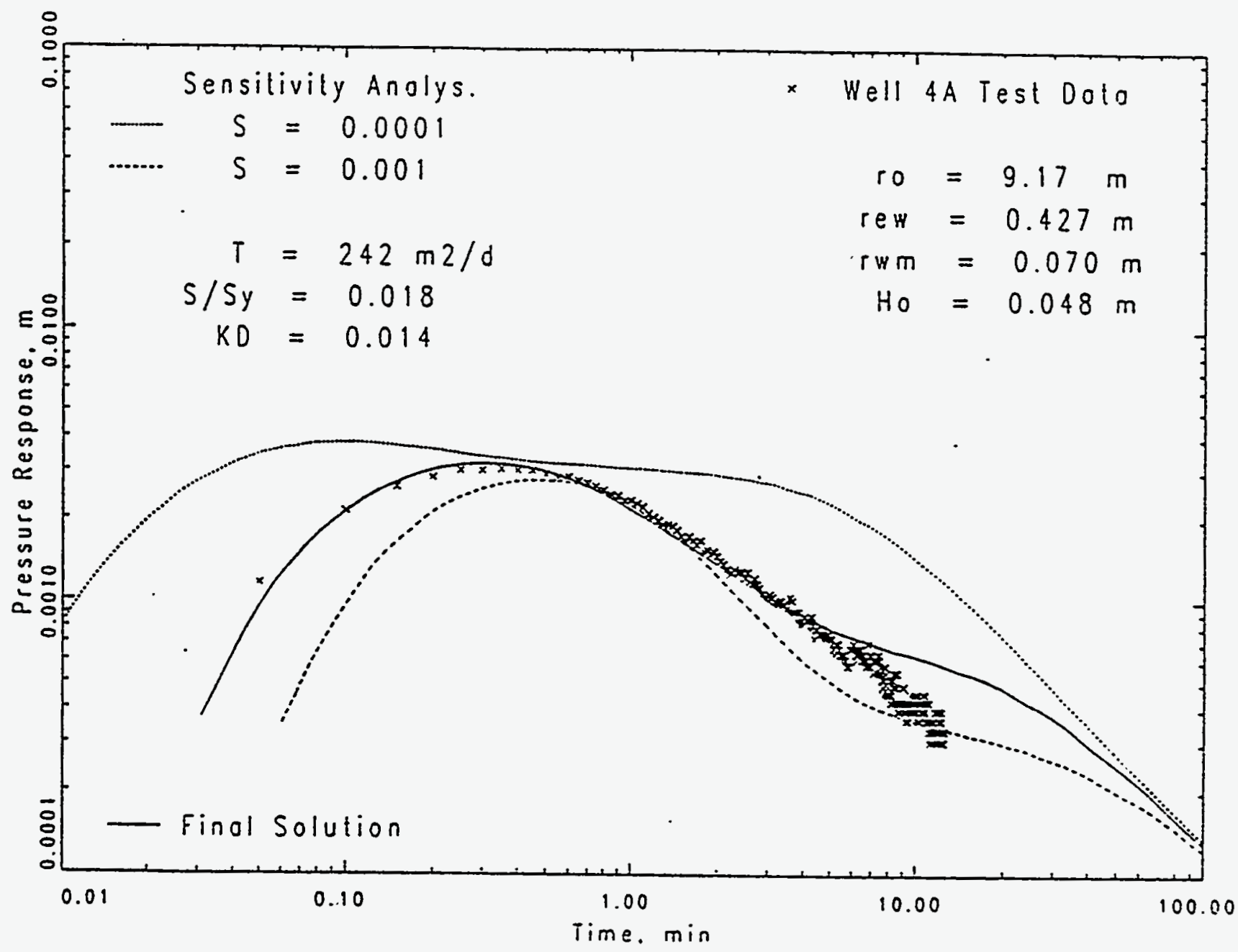

FIGURE 9. Sensitivity of Predicted Slug Interference Response For Well 4A To Varying Storativity $\left(T=242 \mathrm{~m}^{2} / \mathrm{d}, S / \mathrm{S}_{\mathrm{y}}=0.018, K_{j}=0.14\right)$

Note: Hellbore Storage Effects are included 
Mr. Craig Swanson

March 17, 1994

Page 23

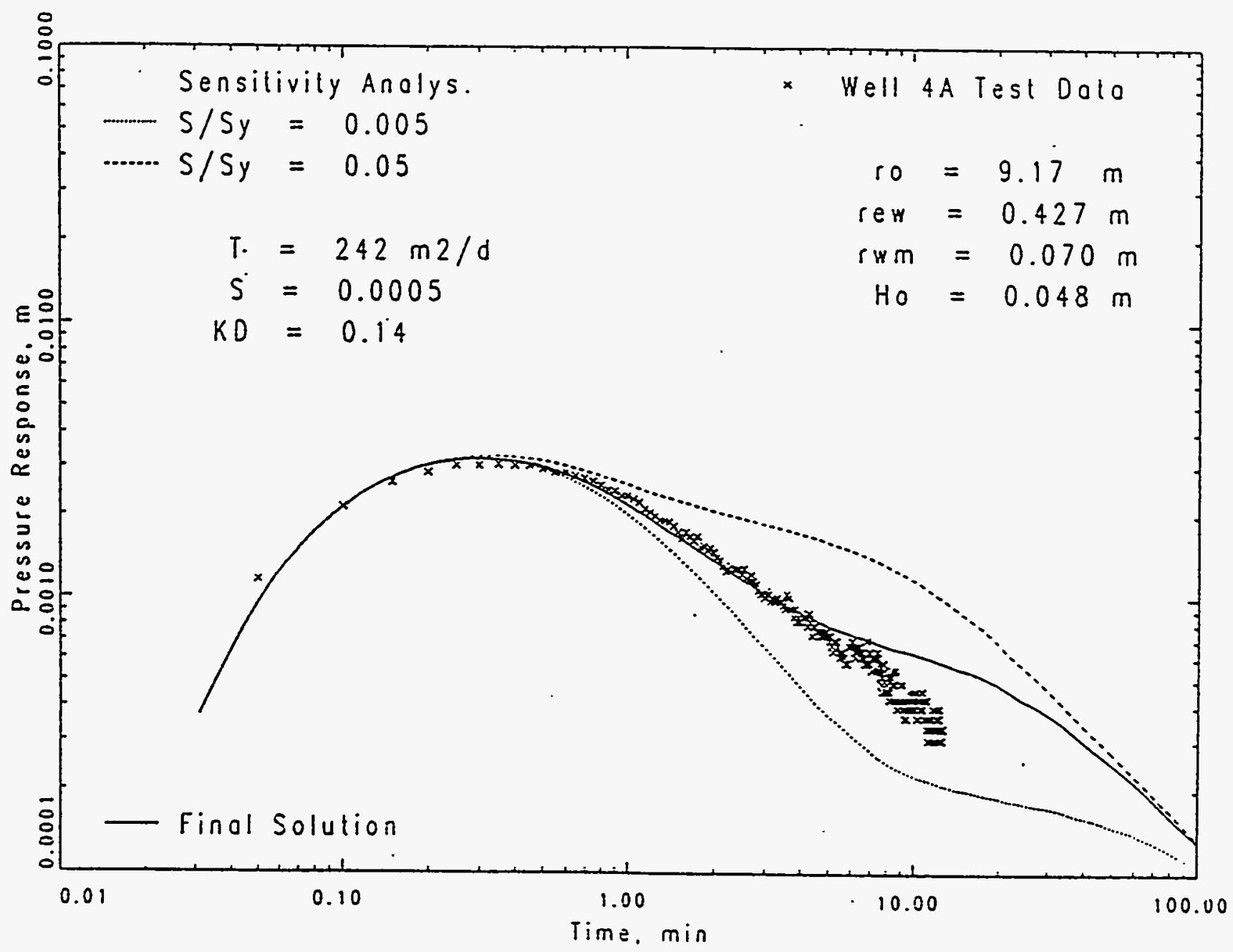

FIGURE 11. Sensitivity of Predicted Slug Interference Response for Well $4 \mathrm{~A}$ To Varying $S / S_{y}\left(T=242 \mathrm{~m}^{2} / d, S=0.0005, K_{j}=0.14\right)$. 
Mr. Craig Swanson

March 17, 1994

Page 25

TABLE 1. Comparison of Hydraulic Test Analysis Results For Well 4A.

\begin{tabular}{lllllllll} 
& \multicolumn{3}{c}{ Re-Analysis Results } & \multicolumn{3}{c}{ Previous Analysis Results* } \\
Test Analysis & $\mathrm{m}^{2} / d$ & $S$ & $S_{y}$ & $K_{0}$ & $\mathrm{~m}^{2} / d$ & $S$ & $S_{y}$ & $K_{D}$
\end{tabular}

\section{Constant-Rate}

Pumping Test

Type B Curve

Anatysis

$254 \quad N A \quad 0.025 \quad 0.15$

NA NA

NA NA

Complete Uncon-

fined Aquifer

Curve Analysis

$254 \quad 0.001$

0.025

0.10

269

$0.0045 \quad 0.016$

0.11

Slug Interference Test**

$242 \quad 0.0005$

0.028

0.14

763

NA

0.012

NA

* Previous analysis reported in Swanson (1992)

** Previous analysis based on the fully penetrating confined aquifer solution method presented in Novakowski (1990); Re-analysis based on the partial penetration unconfined aquifer solution method presented in this letter report

NA Not Applicable 
2. To: (Receiving Organization)

Distribution

5. Proj./Prog./Dept./Div.: Geosciences 8. Originator Remarks:

Document for review and release

3. From: (Originating Organization) Geosciences

6. Cog. Engr.:

L. C. Swanson

11. Receiver Remarks:

12. Major Assm. Dhg. No.:

13. Permit/Permit Application No.:

14. Required Response Date: May 13, 1994

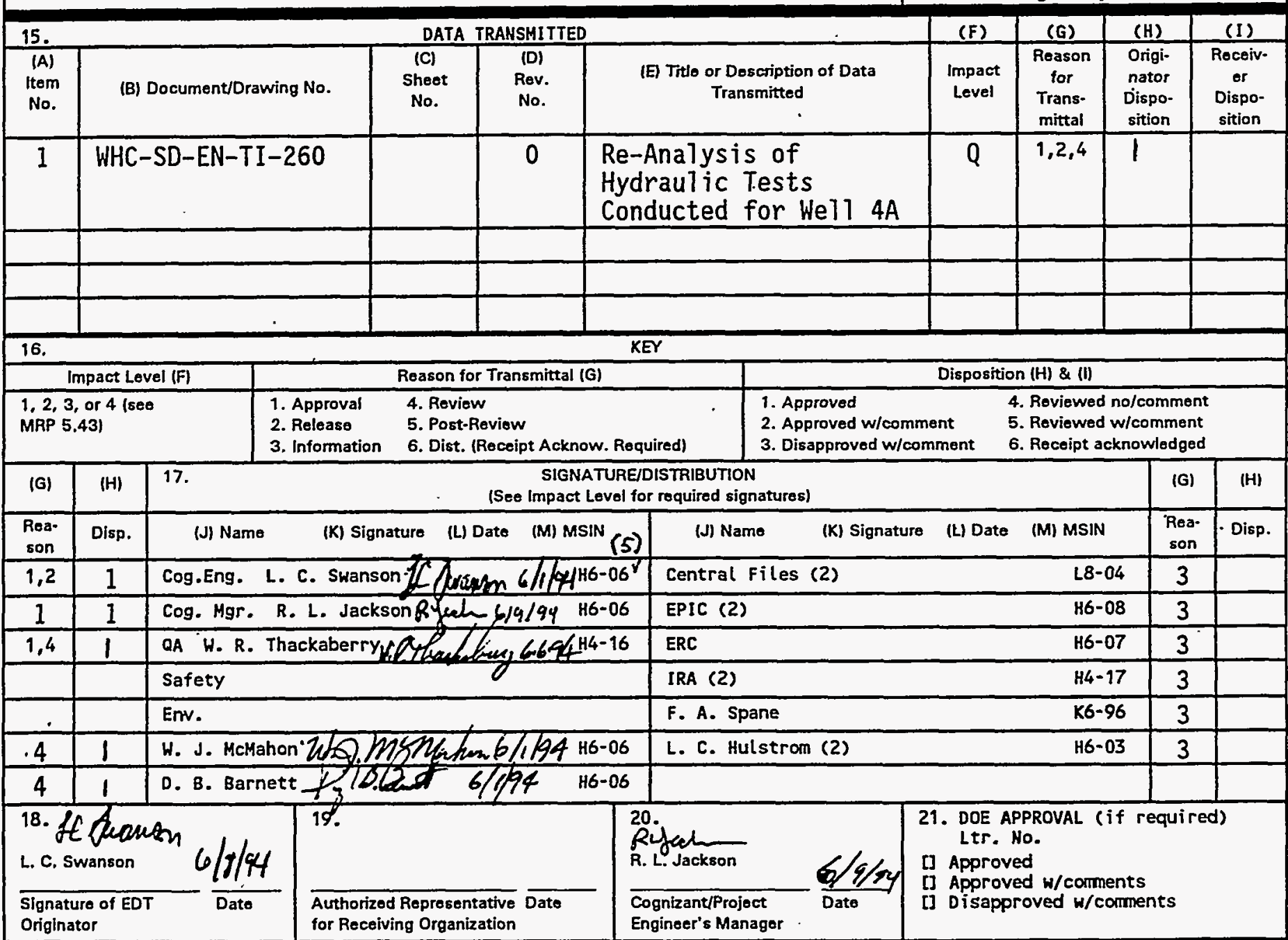

BD-7400-172-2 (07/91) GEF097 


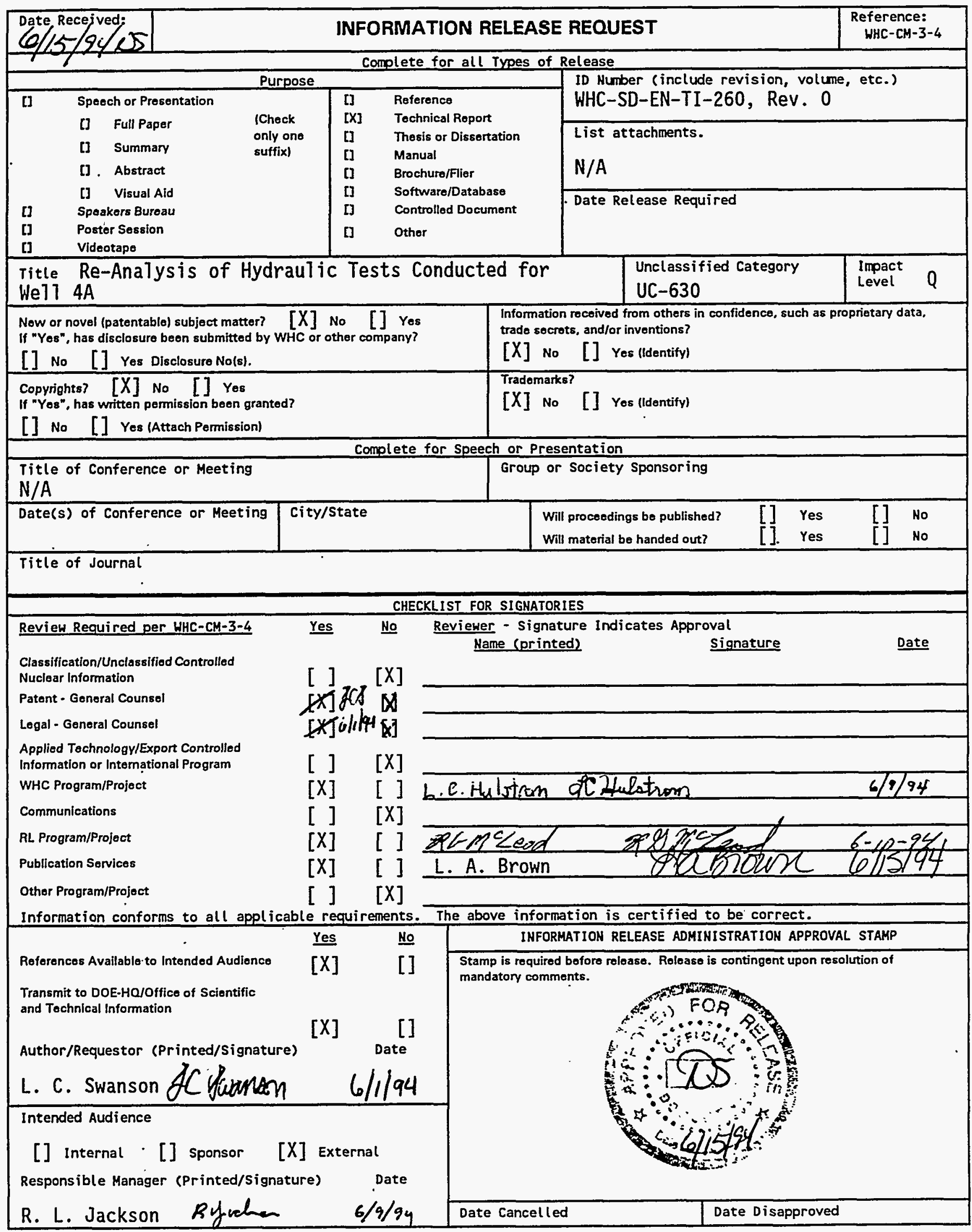




\begin{tabular}{|l|l|c|}
\hline $\begin{array}{l}\text { 2. ritle } \\
\text { Re-Analysis of Hydraulic Tests Conducted for } \\
\text { We } 7 \text { T } 4 \mathrm{~A}\end{array}$ & $\begin{array}{l}\text { 3. Number } \\
\text { WHC-SD-EN-TI-260 }\end{array}$ & $\begin{array}{c}\text { Rev No. } \\
0\end{array}$ \\
$\begin{array}{l}\text { 5. key Hords } \\
\text { constant-rate discharge test, slug interference } \\
\text { test, diagnostic analysis, Type B curve analysis, } \\
\text { unconfined aquifer type-curve analysis }\end{array}$ & $\begin{array}{l}\text { 6. Author } \\
\text { Name: L. C. Swanson } \\
\text { LC Awanom }\end{array}$ \\
\hline $\begin{array}{l}\text { signature } \\
\text { Organization/Charge Code 86950/P25AE }\end{array}$ \\
\hline
\end{tabular}

\section{Abstract APPROVED FOR PUBLIC RELEASE}

WHC, 1994, Re-Analysis of Hydraulic Tests Conducted for Well 4A, WHC-SD-EN-TI-260, Rev. 0, Westinghouse Hanford Company, Richland, Washington.

8. PUR SE AND USE OF D CUMENT - This documert was prepared or use with the U.S. Den tment of Energy and its tractors. $t$ is to be I only perform, direct, or in. ate is under for pub a rel ase until reviewed.

PATENT ST) $S$. This document copy, since it th smitted in advance of tent clearance, is made available confic ce solely for use in performance of work under ontracts th the U.S. Do artmen of Energy. This document $j$ at to be publ ad nor its ctents oth wise disseminated or us for purposes oth than spe fied above b pre patent approval a such release or us. bo in secured, upon quest, from the Pa ent Counsel, U.S. Departm Energy Field offi r, Richland, WA.

DISCLAIMER - This report was prepared as an account of work sponsored by an agency of the United States Government. Heither the United States Government nor any agency thereof, nor any of their employees, nor any of their contractors, subcontractors or their employees, makes any warranty, express or implied, or assumes any legal liability or responsibility for the accuracy, completeness, or any third party's use or the results of such use of any information, apparatus, product, or process disclosed, or represents that its use would not infringe privately owned rights. Reference herein to any specific commercial product, process, or service by trade name, trademark, manufacturer, or otherwise, does not necessarily constitute or imoly its endorsement, recomendation, or favoring by the United States Government or any agency thereof or its contractors or subcontractors. The views and opinions of authors expressed herein do not necessarily state or reflect those of the United States.Government or any agency thereof

9. Impact Level $Q$
10. RELEASE STAMP

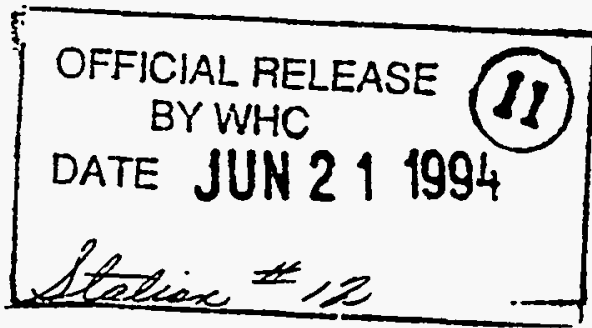




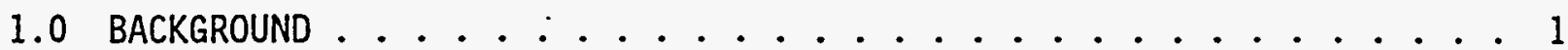

2.0 PUMPING TEST RE-ANALYSIS . . . . . . . . . . . . . . . . 1 2.1 DIAGNOSTIC ANALYSIS ................... 2

2.2 TYPE B CURVE ANALYSIS ..................... 2

2.3 COMPLETE UNCONFINED AQUIFER TYPE-CURVE ANALYSIS . . . . . . . . 5

3.0 SLUG INTERFERENCE TEST RE-ANALYSIS . . . . . . . . . . 8 3.1 TYPE-CURVE ANALYSIS ..................... 11 3.2 SENSITIVITY ANALYSIS ................. 13

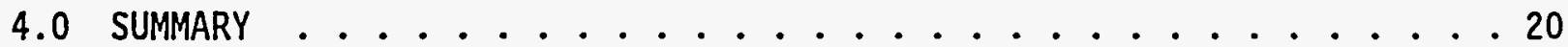

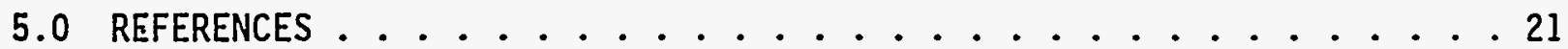

\section{FIGURES:}

1. Diagnostic Drawdown and Drawdown Derivative Plot for Well 4A . . . 3

2. Combined Drawdown and Drawdown Derivative, Type B Curve Analysis for Well 4 A . . . . . . . . . . . . . . . . . 4

3. Slug Test Response at We11 4T; Test Date April 14, 1992 . . . . . . 7

4. Schematic of Slug Test Double Straight-Line Effect . . . . . . . 9

5. Combined Drawdown and Drawdown Derivative, Complete Unconfined Aquifer Type-Curve Analysis for Well $4 \mathrm{~A}$............ . 10

6. Comparison of Pumping Test Drawdown and Drawdown Derivatives and Equivalent Head and Head Derivative Slug Interference Test Response for Well 4A . . . . . . . . . . . . . . . 12

7. Unconfined Aquifer Type-Curve Analysis for Slug Interference Test Response for Well 4 A.................. 14

8. Sensitivity of Predicted Slug Interference Response for Well 4A to Varying Transmissivity . . . . . . . . . . . . . . . 15

9. Sensitivity of Predicted STug Interference Response for Well 4A to Varying Storativity .................... . 16

10. Sensitivity of Predicted Slug Interference Response for Well 4A to Wellbore Storage Effects................. 17

11. Sensitivity of Predicted Slug Interference Response for Well 4A

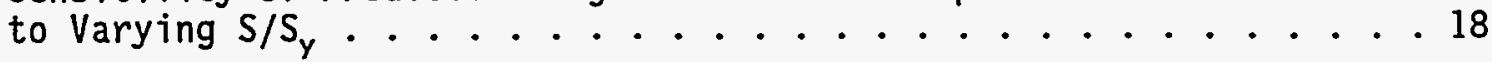

12. Sensitivity of Predicted Slug Interference Response for Well 4A to Varying $K_{D}$ 
WHC-SD-EN-TI-260, Rev. 0

CONTENTS, (cont.)

\section{TABLE:}

1. Comparison of Hydraulic Test Analys is Results for Well 4A . . . . 20 


\subsection{BACKGROUND}

During 1992, a series of hydrologic characterization tests were conducted at the well 4A - 4T test facility complex. Details concerning these tests are described in Swanson (1992). Two of the tests, a constant-rate discharge test conducted on March 30, 1992 and a slug interference test performed on April 15, 1992, are the focus of this report.

Preliminary analysis results presented in Swanson (1992) indicated a significant divergence in hydraulic property estimates (i.e., transmissivity and storativity/specific yield) obtained for the pumping test and slug interference test. The divergence in hydraulic property estimates is attributed to several deficiencies in the original slug interference analysis. The original slug interference test analysis was based on the procedure presented in Novakowski (1990), which is dependent on fully penetrating wells within isotropic confined aquifer conditions. Subsequent to this analysis, analytical methods have been developed, which provide the opportunity of extending slug interference analysis to a variety of test conditions including:

- Unconfined aquifers

- Partially penetrating wells

- Anisotropic conditions

- Wellbore storage effects (for the pumped well).

In addition, it is al so noted that an incorrect stress level, i.e., $H_{0}$ value of $0.536 \mathrm{~m}(1.76 \mathrm{ft})$, for the slug interference test was used in the original analysis presented in Swanson (1992).

As part of the re-analysis effort, the results from the pumping test conducted at we 71 4T and observed at well 4A were re-examined. While significant changes were not expected from the pumping test re-analysis for estimates of transmissivity and specific yield, a revised estimate for storativity was anticipated: An amended value for storativity was expected because the original pumping test analysis method did not take into account the effects of wellbore storage in observation well 4A. It is important to note that the storativity or elastic storage characteristics of the aquifer exert a strong influence on slug interference amplitude, as noted previously in Novakowski (1990) and Spane (1992). For these reasons, the pumping test results for well $4 \mathrm{~A}$ were re-analyzed.

\subsection{PUMPING TEST RE-ANALYSIS}

The re-analysis procedure for the drawdown portion of the pumping test at well $4 \mathrm{~A}$ included the following analysis elements:

- An initial diagnostic drawdown derivative analysis

- A Tate-time, Neuman Type B curve analysis

- A complete unconfined aquifer type-curve analysis, including wellbore storage effects. 


\subsection{DIAGNOSTIC ANALYSIS}

Combined drawdown and drawdown derivative plots have been shown to be a powerful diagnostic tool in identifying operative flow conditions and factors influencing drawdown during constant discharge pumping tests (e.g., Bourdet et a1. 1983, 1989; Spane 1993). Figure 1 shows the combined drawdown and drawdown derivative plot for observation well 4A. The drawdown derivatives were calculated using the DERIV program described in Spane and Wurstner (1993). Based on a diagnostic analysis of the pattern exhibited in Figure 1, the following operative flow conditions during the test were interpreted:

- Combined wellbore storage and delayed-yield response conditions during the early phases of the test (i.e., up to $\approx 4 \mathrm{~min}$ )

- Unconfined aquifer, Type B curve response characteristics between 4 and 500 min

- Variable drawdown/derivative pattern after $500 \mathrm{~min}$, most likely attributable to discharge fluctuations.

\subsection{TYPE B CURVE ANALYSIS}

To provide an initial estimate of transmissivity and specific yield, drawdown data during the test period indicative of Neuman unconfined aquifer, Type B curve behavior were analyzed (i.e., for test times $\geq 4 \min$ ). The combined Type B drawdown and drawdown derivative plot matching procedure described in Spane (1993) was used in the test analysis. Drawdown type curves were generated using the WTAQ1 program described by Moench (1993). As discussed in Moench (1993), the WTAQI program runs faster and does not exhibit some of the test instabi7ities that are sometimes exhibited with the DELAY2 program described by Neuman (1975) for analysis of unconfined aquifer pumping tests. Associated derivative plots of the Type B curves were generated, as discussed previously, using the DERIV program.

The combined drawdown and derivative plot match for the test is shown in Figure.2. As indicated in Figure 2, a very close match was obtained for the combined drawdown and derivative plot for the identified test period exhibiting Type $B$ drawdown behavior (i.e., $\geq 4$ min). Results of the analysis indicate estimates for transmissivity and specific yield of $254 \mathrm{~m}^{2} / \mathrm{d}$ $\left(2,730 \mathrm{ft}^{2} / \mathrm{d}\right)$ and 0.025 , respectively. A qualitative estimate for vertical anisotropy $\left(K_{0}\right)$ of 0.15 is also suggested. These results compare favorably with preliminary unconfined aquifer analysis results for transmissivity $\left(269 \mathrm{~m}^{2} / \mathrm{d}\right)$, specific yield $(0.016)$, and vertical anisotropy $(0.11)$ reported in Swanson (1992), which were obtained from automated type-curve analysis of the entire-drawdown record using the ISOAQX program (HydraLogic 1989). 
WHC-SD-EN-TI-260, Rev. 0

Figure 1. Diagnostic Drawdown and Drawdown Derivative Plot for We17 4A.

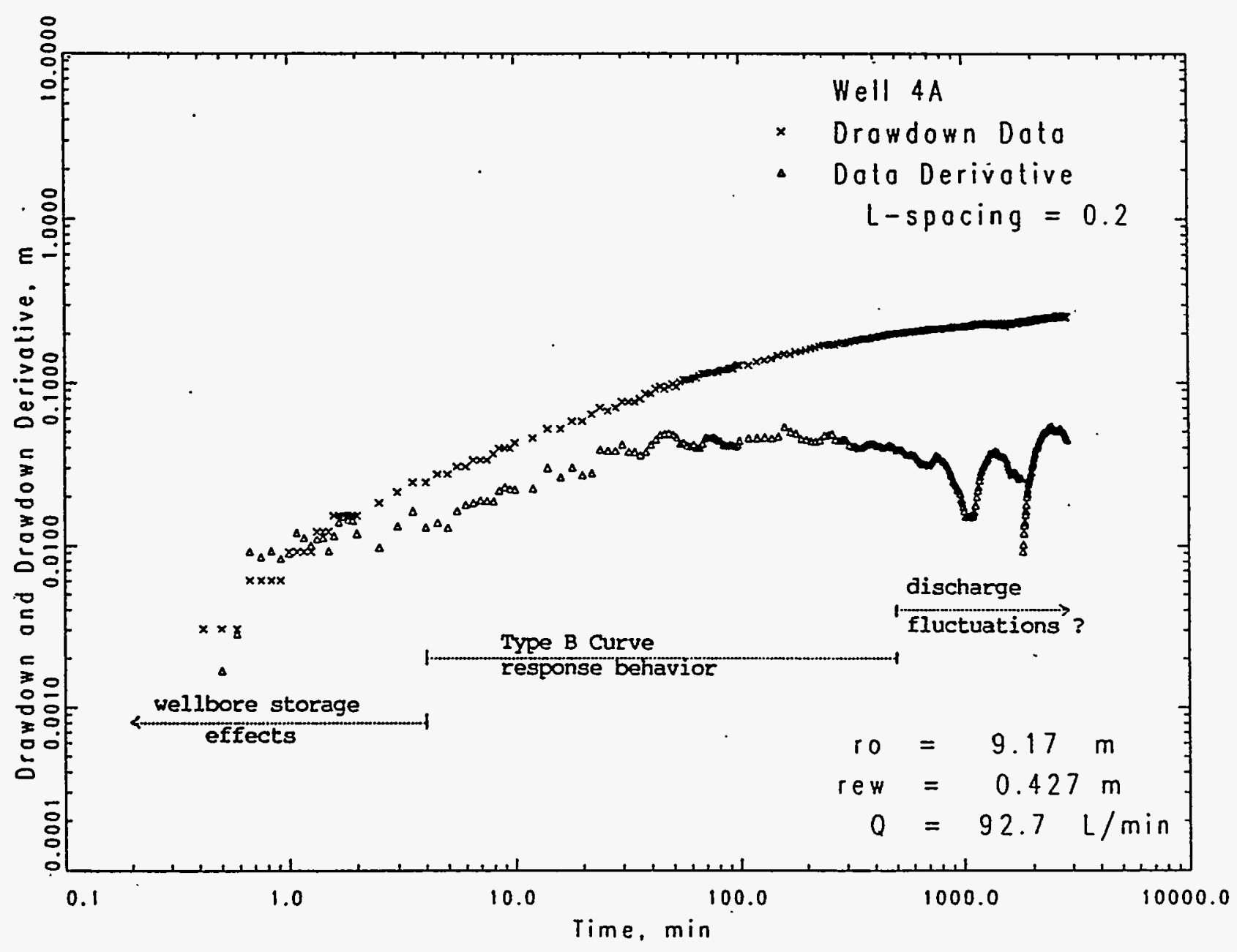


Figure 2. Combined Drawdown and Drawdown Derivative, Type B Curve Analys is for Well 4A.

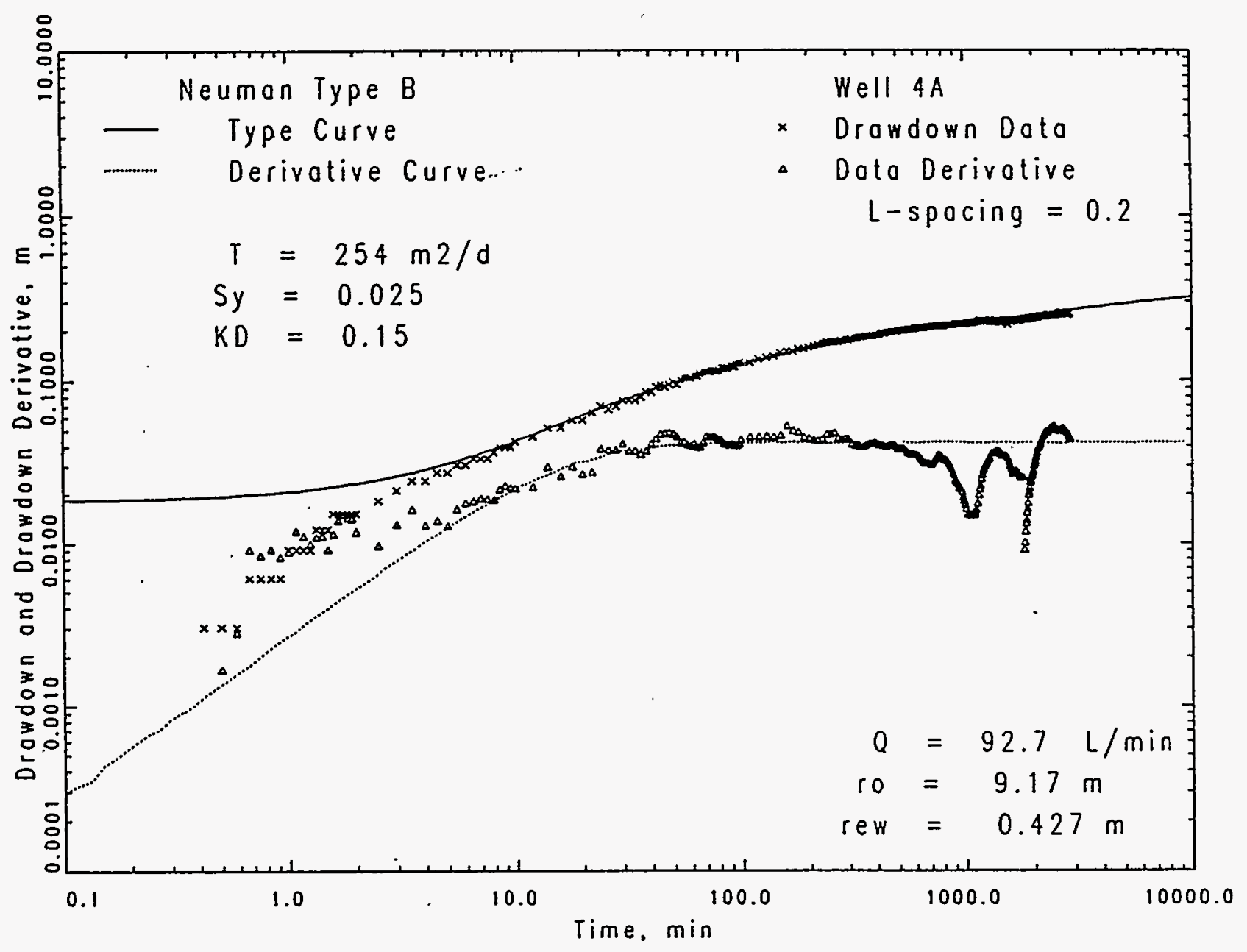




\subsection{COMPLETE UNCONFINED AQUIFER TYPE-CURVE ANALYSIS}

An additional analysis was also attempted that analyzed the entire time drawdown data set. The complete data analysis followed the same procedure described in Section 2.2 for the Type B curve analysis. The complete unconfined aquifer analysis procedure, however, includes the effects of wellbore storage, which would be expected to be exhibited during the early phases of the test. Wellbore storage effects were accounted for, utilizing an undocumented program that simulates wellbore storage effects, which is based on the procedure described in Fenske (1977). The undocumented program can be used to account for pumping and observation wellbore storage effects. A comparison of results obtained with the Fenske-based program indicated nearly identical results when compared with predictive responses (i.e., for pumping well wellbore storage) generated with the Novakowski (1990) program for confined aquifers, and the program provided in Dawson and Istok (1991) for unconfined aquifer Type A curve response.

To fully account for the effects of wellbore storage, the "effective" well radius, $r_{e x}$; for the pumped and observation wells is required. As will be shown, the effective well radius for the pumped well $4 \mathrm{~T}$ is considerably greater than for observation well 4A. The early-time drawdown pattern in the vicinity of the pumping well (i.e., within a distance of $\approx 100$ wellbore radii), therefore, is expected to be affected more by pumping well (rather than observation wel1) wellbore storage effects.

For wells with sand/gravel pack installations, the effective well radius can be calculated using the following relationship presented in Bouwer (1989):

$$
r_{e w}=\left[(1-n) r_{c}^{2}+n r_{w}^{2}\right]^{1 / 2}
$$

where

$$
\begin{aligned}
& r_{c}=\text { radius of the well screen } \\
& r_{w}=\text { radial distance from center of well to the outside sand/gravel } \\
& \text { pack } \\
& . n=\text { porosity of the sand/gravel pack. }
\end{aligned}
$$

For well 4A, given a well screen radius of $0.051 \mathrm{~m}(0.1667 \mathrm{ft})$, a radial gravel pack distance of $0.102 \mathrm{~m}(0.333 \mathrm{ft})$, and an assumed porosity of $30 \%$, yields a $r_{\text {ew }}$ for we17 4 A of $0.070 \mathrm{~m}(0.230 \mathrm{ft})$.

A calculation of the $r_{e x}$ for the pumped well (well 4T), however, is more difficult because of the "natural" sand/gravel pack that was developed around the we11, during previous wellbore developmental pumping. As noted in Swanson (1992), several barrels of sand and silt were removed from well 4T during the developmental pumping phase. The presence of an extensive zone of "enhanced" permeability surrounding the immediate wellbore is indicated also by the 
bi-linear response exhibited at well $4 \mathrm{~T}$ during the slug test (Figure 3 ). As a means of estimating possible values for the $r_{e w}$ for well $4 T$, the radial distance, $r_{w}$, to the outside boundary of the developed "natural" sand/gravel pack calculated based on the known displacement, $V_{t}=0.027 \mathrm{~m}^{3}\left(0.96 \mathrm{ft}^{3}\right)$ and initial stress response, $H_{0}=0.168 \mathrm{~m}(0.55 \mathrm{ft})$ observed at well $4 \mathrm{~T}$ during the April 14, 1992 slug test (see Figure 3). For this calculation, the following relationships were developed:

$$
V_{t}=V_{w c}+V_{w a}
$$

where

$$
\begin{aligned}
& V_{t}=\text { slug test volume displacement }\left(0.027 \mathrm{~m}^{3}\right) \\
& V_{w c}=\text { displacement volume within well screen } \\
& V_{w a}=\text { displacement volume within natural sand/gravel pack zone }
\end{aligned}
$$

where

$$
V_{w c}=\pi r_{c t}^{2} H_{0}=0.0067 \mathrm{~m} ;\left(0.237 \mathrm{ft}^{3}\right)
$$

where

$r_{c t}=$ radius of well $4 \mathrm{~T}$ well screen; $0.113 \mathrm{~m}(0.370 \mathrm{ft})$.

-

Re-arranging Equation 2,

$$
V_{w a}=V_{t}-V_{w c}=0.020 \mathrm{~m}^{3} ;\left(0.723 \mathrm{ft}^{3}\right)
$$

Also note that from a modification of a relationship in Bouwer (1989)

$$
V_{\mathrm{Ha}}=\pi\left(r_{\mathrm{w}}^{2}-r_{c}^{2}\right) n H_{0}
$$

For $n$ values ranging from $15 \%$ to $30 \%$, calculated. $r_{\text {values }}$ range between $0.521 \mathrm{~m}$ to $0.378 \mathrm{~m}$ ( $1.71 \mathrm{ft}$ to $1.24 \mathrm{ft}$ ), respectively. Using these range of $r_{w}$ and $n$ values in Equation 1 yields an estimated effective well radius, $r_{\text {ew }}$, of $0.229 \mathrm{~m}(0.75 \mathrm{ft})$.

The effective well radius value of $0.229 \mathrm{~m}$ would be expected to provide a valid prediction of wellbore storage effects for test conditions where the hydraulic properties of the natural sand/gravel pack zone are similar to that of the surrounding test formation. However, as shown in Figure 3 , the "double straight-line pattern" displayed during the slug test at well 4 T indicates that the developed zone around the well possesses a significantiy greater transmissivity than the surrounding formation. This developed inner zone of greater transmissivity causes the surrounding test formation response to react 
WHC-SD-EN-TI-260, Rev. 0

Figure 3. Slug Test Response at We11 4T; Test Date: April 14, 1992 (adapted from Swanson 1992).

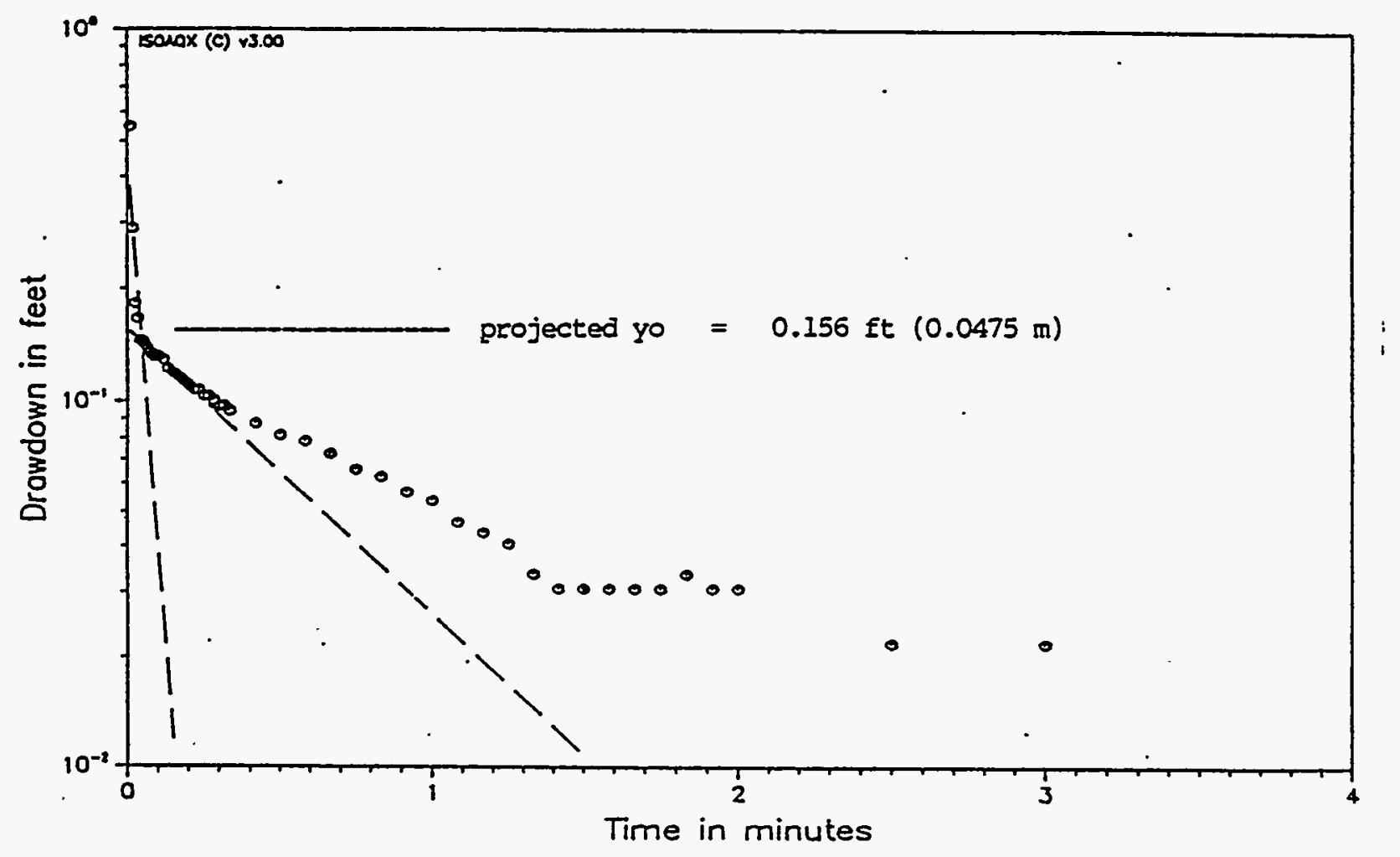


more rapid7y. In the petroleum industry, wells with inner zones of enhanced permeability are referred to as having a negative skin effect. As indicated by Earlougher (1977), the effective well radius, $r_{\text {ex, }}$, for wells exhibiting negative skins is greater than the observed or calculated well radius, $r_{w}$.

To estimate the "enhanced" effective well radius, $r_{\text {eew }}$, at well 4T, an analysis technique presented in Bouwer (1989) was adapted. When double straight-line conditions are exhibited during slug testing, Bouwer (1989) states that the observed initial stress value $\left(y_{t}\right)$ should not be used in the analysis, but rather the projected initial stress value $\left(y_{0}\right)$ as shown in Figure 4. The projected $y_{a}$ stress value is what is actually imposed on the test formation (i.e., outside the inner developed zone of enhanced permeability). The projected $y_{0}$ value of $0.0475 \mathrm{~m}(0.156 \mathrm{ft})$ from Figure 3 and known slug test stress volume (i.e., slugging rod volume $=0.027 \mathrm{~m}^{3}$ ) can then be used in the following re-arrangement of the volume equation for a cylinder to provide an "enhanced" effective well radius estimate.

$$
r_{\text {eew }}=\left[V_{t} /\left(\pi y_{0}\right)\right]^{1 / 2}
$$

Based on this procedure, an $r_{\text {eew }}$ estimate of $0.427 \mathrm{~m}(1.4 \mathrm{ft})$ was obtained. This estimate for the "enhanced" effective well radius was used in the re-analysis of the constant-rate pumping test (i.e., complete unconfined aquifer type-curve analysis) and slug interference test.

Figure 5 shows the final result of matching the observed drawdown and drawdown derivative with a complete unconfined aquifer type curve and derivative plot. As indicated, a close match was obtained for the combined drawdown and drawdown derivative plot. Results from the completed unconfined aquifer curve analysis indicated the following hydraulic parameter estimates: transmissivity $=254 \mathrm{~m}^{2} / \mathrm{d}\left(2,730 \mathrm{ft}^{2} / \mathrm{d}\right)$, specific yield $=0.025$, storativity $=$ 0.001 , and vertical anisotropy $=0.10$. These results are very similar to results obtained with the Type $B$ curve analysis and to those previousiy reported by Swanson (1992). It should be noted, however, that the estimate for storativity is considered to be very qualitative, primarily because of the lack of early-time data (i.e., the first 25 seconds) and the lack of sensitivity for small drawdown measurements (note the "stair-stepped" pattern for drawdowns $<0.015 \mathrm{~m}$ ).

\subsection{SLUG INTERFERENCE TEST RE-ANALYSIS}

As noted in Section 1.0, the original slug interference test analysis was based on the analysis procedure presented in Novakowski (1990), which is dependent on fully penetrating wells within isotropic confined aquifer conditions. Subsequent to this analysis, analytical methods have been developed, which provide the opportunity of extending slug interference analys is to a variety of test conditions including unconfined aquifers, partially penetrating wells, anisotropic conditions, and wellbore storage effects. The analysis extension is based on analytical discussions presented 


$$
\text { WHC-SD-EN-TI-260, Rev. } 0
$$

Figure 4. Schematic of Slug Test Double Straight-Line Effect (adapted from Bower 1989).

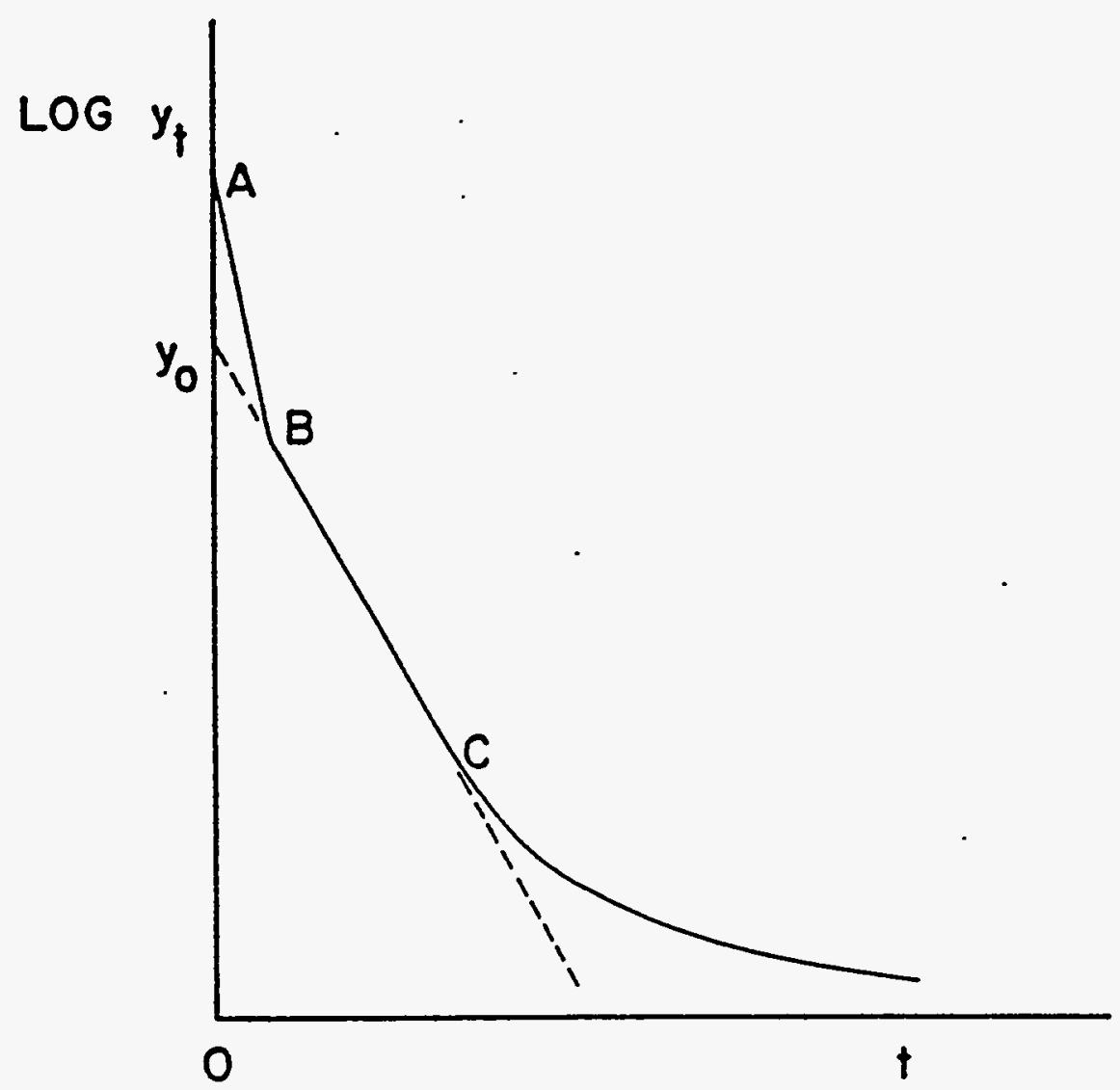

9 
Figure 5. Combined Drawdown and Drawdown Derivative, Complete Unconfined Aquifer Type-Curve Analys is for Well 4A.

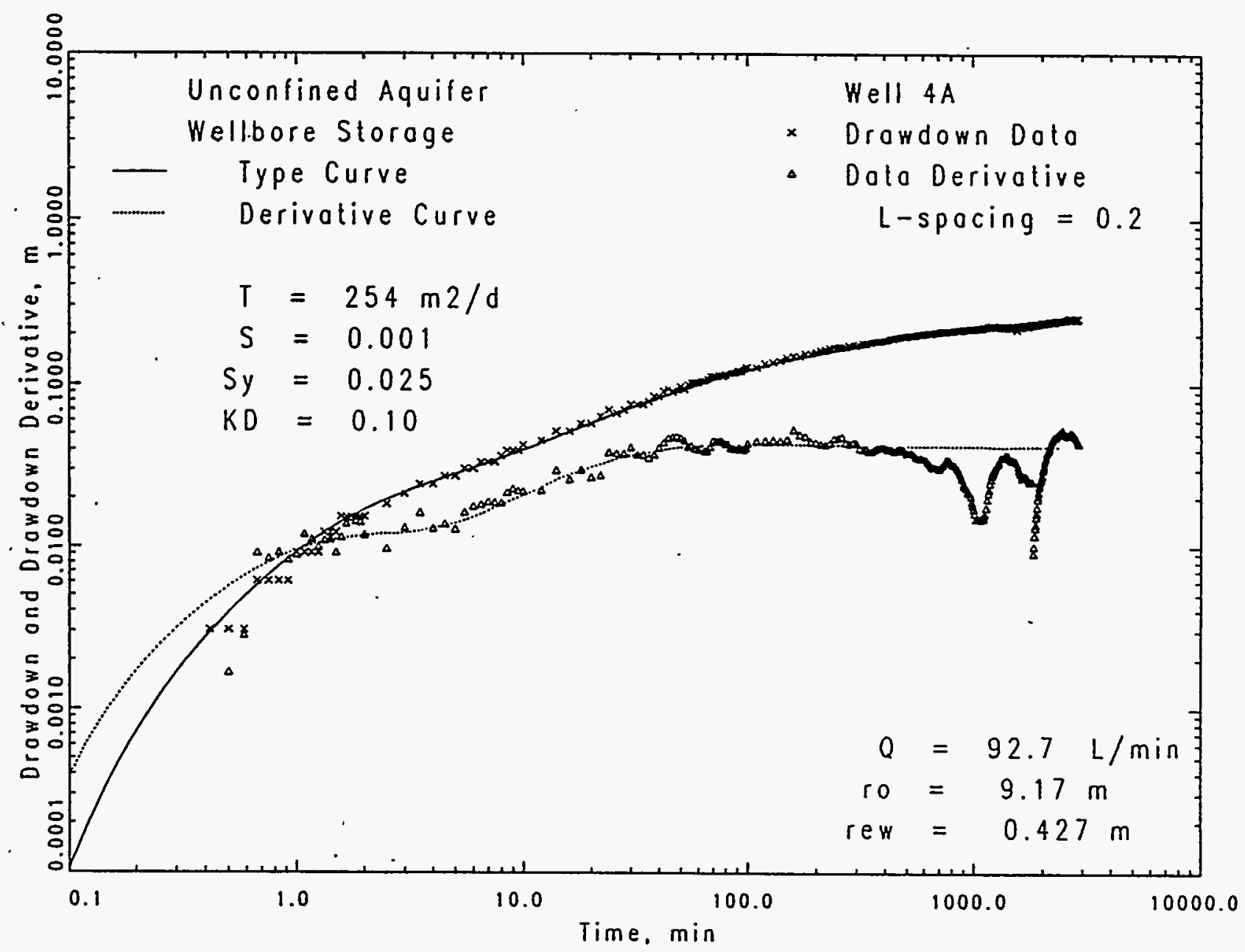


in Novakowski (1989), Peres (1989), and Peres et al. (1989), which demonstrate that slug tests can be represented as a specialized form of constant-rate pumping tests. As noted in Peres (1989), the slug test wellbore solution can be "... obtained directly from the time derivative of the constant rate wellbore storage solution ... (and that this relationship) is also valid for any reservoir/well system and holds at any position within the reservoir."

A detailed description of the procedures for slug test conversion is not presented here. The reader should consult the aforementioned references for analytical justification of the slug test conversion method. Briefly stated, however, slug test data were converted to equivalent head (pumping test) drawdown data by integrating the observed slug test head data over the observed test time, as indicated in Peres et al. (1989). Multiplication of the observed slug test head data by the observed test time yields the logarithmic derivative of the equivalent head change for a constant-rate pumping test.

Figure 6 shows a comparison of the drawdown and drawdown derivative response observed at well $4 \mathrm{~A}$ during the constant-rate pumping test with the converted equivalent head and head derivative response obtained during the slug interference test. As indicated in Figure 6, similar pattern shapes are exhibited. To equate the two test responses, however, the stress levels for the two tests need to be normalized.

As noted in Novakowski (1989) and Peres et al. (1989), the instantaneous discharge rate, $Q_{i}$, (gal/min), imposed by a slug test can be calculated directly by the displacement volume, $V_{t}$. For a displacement volume of $0.027 \mathrm{~m}^{3}\left(0.96 \mathrm{ft}^{3}\right)$, a $Q_{i}$ value of $27.2^{\mathrm{t}} \mathrm{L} / \mathrm{min}(7.18 \mathrm{gal} / \mathrm{min})$ is indicated. To normalize the slug test derived results to the drawdown observed during the constant-rate pumping test, the equivalent head drawdown data were multiplied by a factor of 3.41 , which represents the ratio of the two discharge rates (i.e., $92.7 \mathrm{~L} / \mathrm{min} / 27.2 \mathrm{~L} / \mathrm{min}$ ). As indicated by the normalized equivalent head response, a close correspondence between the pumping test drawdown and equivalent head/slug test results is indicated. It should also be noted that the time period of slight drawdown departure (i.e., after $\approx 7 \mathrm{~min}$ ) represents a time period during the test when the slug interference response had decayed to a value of $0.0006 \mathrm{~m}(0.002 \mathrm{ft})$ or less. No great significance, therefore, should be placed on this slight deviation.

\subsection{TYPE-CURVE ANALYSIS}

For generating predicted siug interference unconfined aquifer type curves for the given well site test conditions, predicted pumping test drawdown curves were first generated using the WTAQI program, using given test site conditions (e.g., $r_{f}, Q, r_{e y}$ ) and selected hydraulic parameter values (e.g., T, S, $S_{y}, K_{0}$ ). Effects of wellbore storage were accounted for using the program described in Section 2.3, which is based on the Fenske (1977) method. Drawdown derivatives were calculated using the DERIV program presented in Spane and Wurstner (1993). Slug interference responses were then generated by dividing the calculated pumping test derivative by the test time. The well 4A test response was analyzed by matching the generated slug interference type curves to the observed slug interference data. The type-curve analysis procedure continued iteratively by varying the value for input parameters $T, S, S_{y}$, and $K_{D}$ until a visually acceptable match was obtained. 
Figure 6. Comparison of Pumping Test Drawdown and Drawdown Derivatives and Equivalent Head and Head Derivative Slug Interference

Test Response for Well 4A.

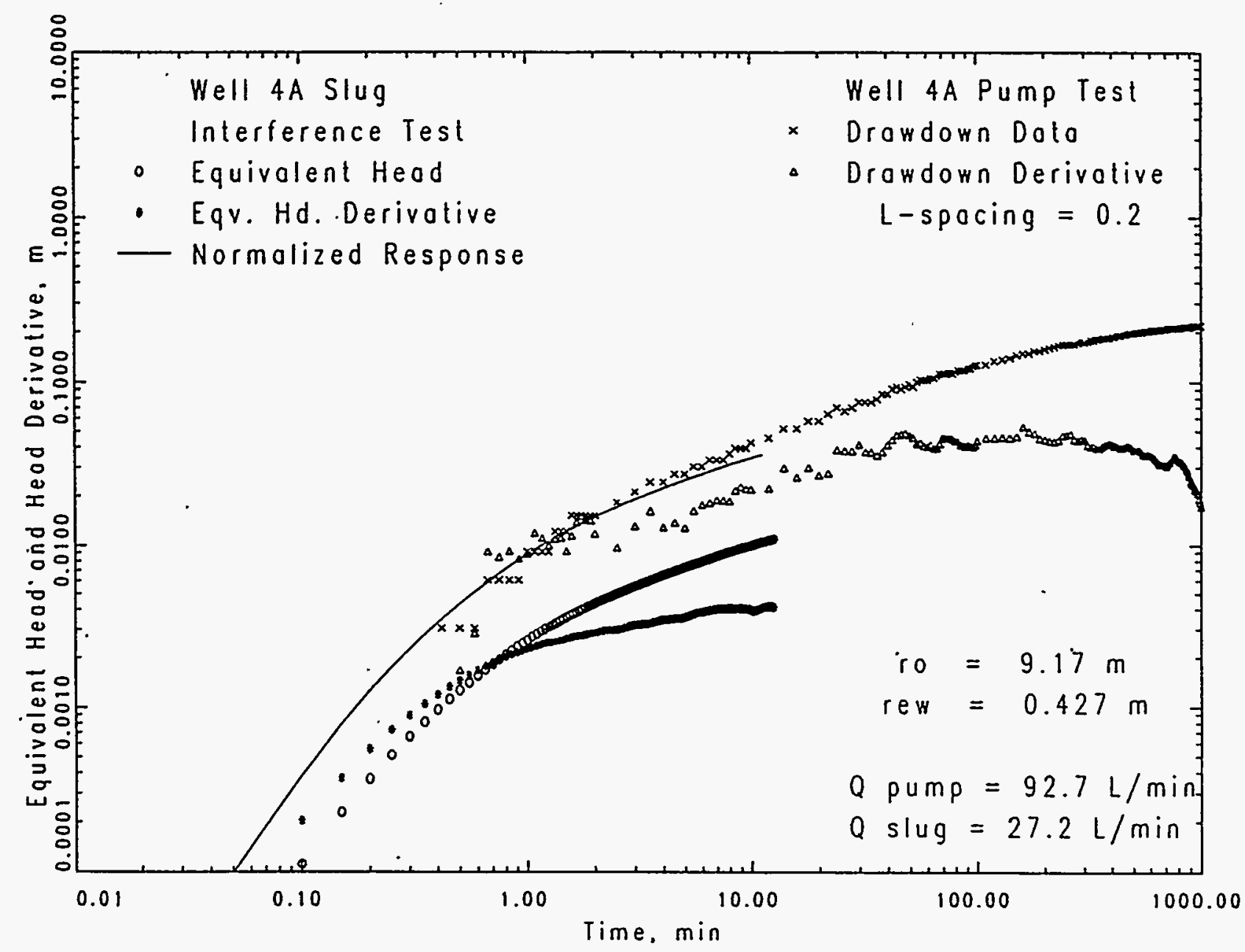


Figure 7 shows the resulting best-fit unconfined aquifer type curve match. Emphasis in the analysis was primarily placed on matching the observed response in the central portion (i.e., the "hump") of the slug interference response. Less emphasis was placed on matching late-time (i.e., $\geq 7 \mathrm{~min}$ ), because of the extremely small (i.e., $\leq 0.0006 \mathrm{~m}$ ) and somewhat erratic nature of the observed measurements. As indicated in Figure 7, a close match was obtained for most of the observed slug interference response. Results of the analysis indicate estimates for transmissivity and storativity of $242 \mathrm{~m}^{2} / \mathrm{d}$ $\left(2,600 \mathrm{ft}^{2} / \mathrm{d}\right)$ and 0.0005 , respectively. A more qualitative estimate for vertical anisotropy $\left(K_{0}\right)$ of 0.14 and for specific yield of 0.028 is also suggested. These results compare favorably with results obtained from the unconfined aquifer type-curve analyses presented in Sections 2.2 and 2.3.

\subsection{SENSITIVITY ANALYSIS}

Slug interference test response is a function of the applied stress, test well/aquifer relationships (i.e., well diameter, radial distance, aquifer thickness, well penetration characteristics), and test formation hydraulic properties ( $j . e ., T, S, S_{y}$, and $K_{0}$ ). If it is assumed that the applied stress and test we11/aquifer relationships are known for the test, an infinite number of predictive response shapes are still possible. The number of predictive responses can be greatly reduced, however, if expected (common) bounds can be applied for some of the formation hydraulic properties. Limits used for slug interference type curves generated for the analysis of the well 4A test response included $S_{y}=0.005$ to $0.4, S=10^{-4}$ to $10^{-1}, K_{b}=0.01$ to 1.0 , and $T=10^{1}$ to $10^{4} \mathrm{~m}^{2} / \mathrm{d}\left(10^{2}\right.$ to $\left.10^{5} \mathrm{ft}^{2} / \mathrm{d}\right)$.

To examine the sensitivity of the predicted slug interference response to various hydraulic property combinations, individual type curves were generated by systematically varying selected parameter estimates. Figures 8 through 12 show the results of the sensitivity analysis. As expected, variation in the selected hydraulic property values causes significant changes in the shape and amplitude of the predicted slug interference response. The following general observations are provided that summarize the sensitivity of the predicted slug interference response to hydraulic property variation (i.e., given well 4 A test site conditions).

- Transmissivity is the principal parameter controlling the transmission (i.e., arrival time) of the interference response (Figure 8).

- Storativity exerts a significant influence on the amplitude and shape of the initial slug interference "hump" (Figures 9 and 10 ).

- Wellbore storage effects dampen and delay transmission of the initial slug interference response observed (Figure 10). 
WHC-SD-EN-TI-260, Rev. 0

Figure 7. Unconfined Aquifer Type-Curve Analysis for Slug Interference Test Response for Well 4A.

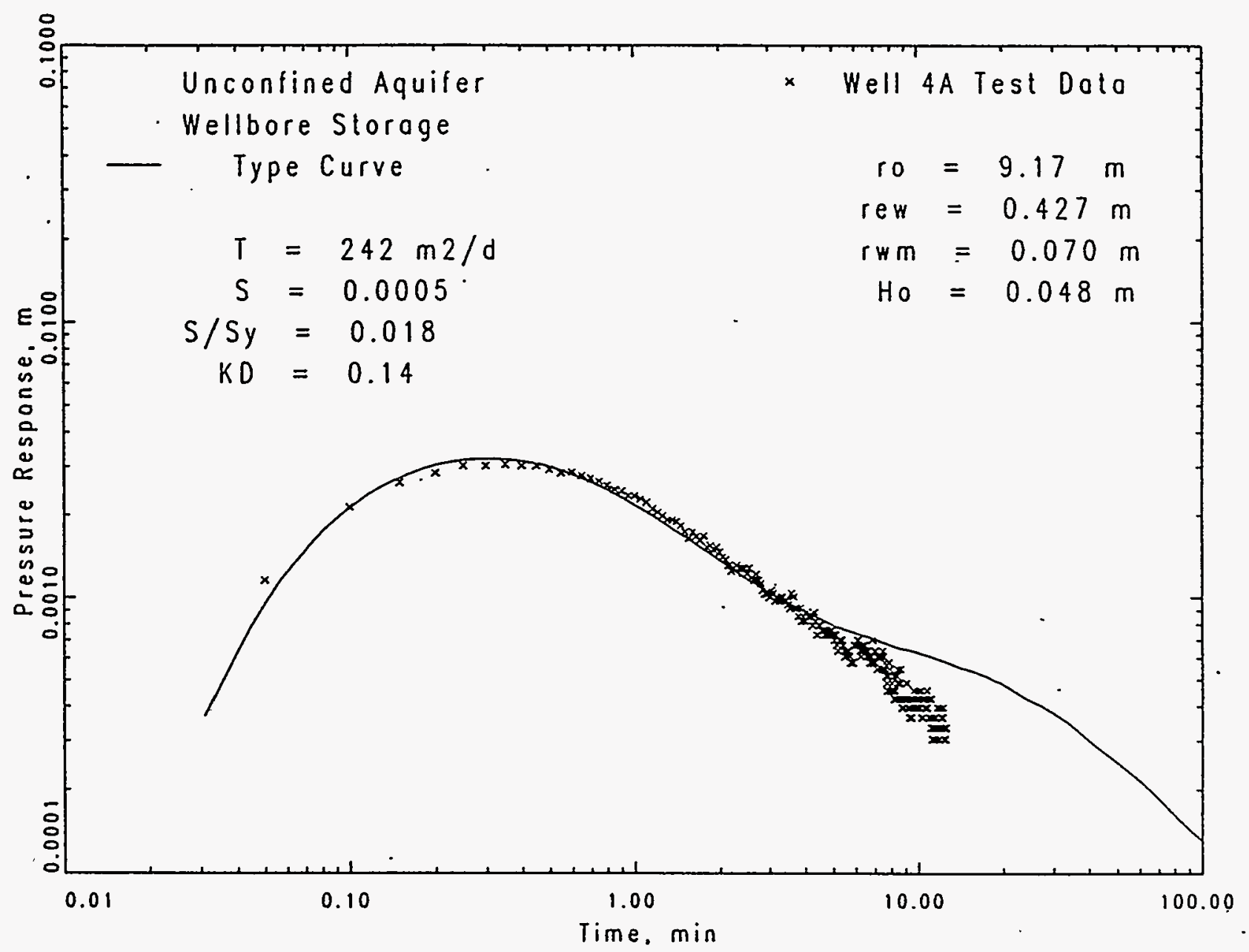


Figure 8. Sensitivity of Predicted Slug Interference Response for Well $4 \mathrm{~A}$ to Varying Transmissivity $\left(S=0.0005, S / S_{y}=0.018, K_{D}=0.14\right)$.

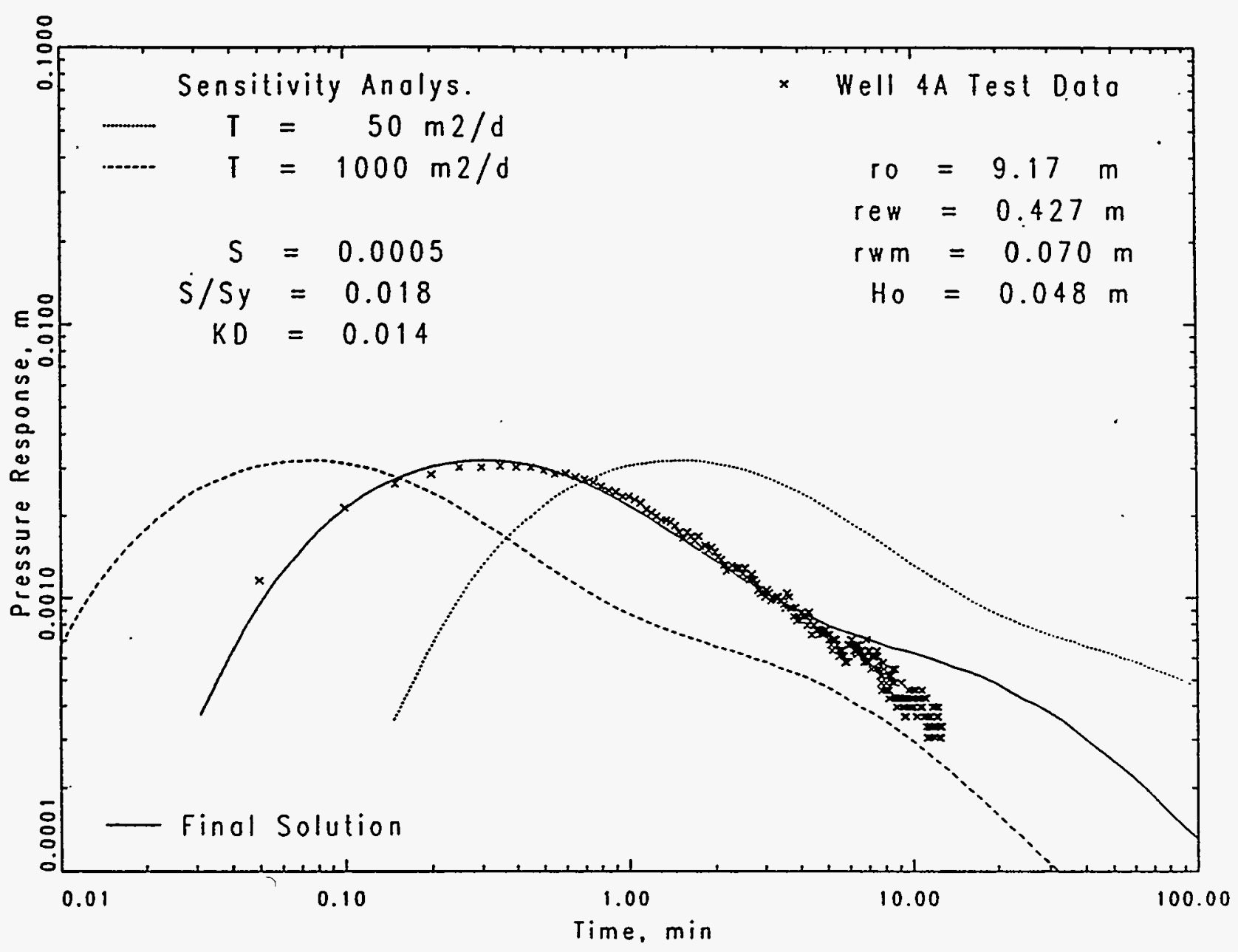


Figure 9. Sensitivity of Predicted Slug Interference Response for Well $4 \mathrm{~A}$ to Varying Storativity $\left(T=242 \mathrm{~m}^{2} / \mathrm{d}, \mathrm{S} / \mathrm{S}_{\mathrm{y}}=0.018, \mathrm{~K}_{\mathrm{D}}=0.14\right)$

(wellbore storage effects are included).

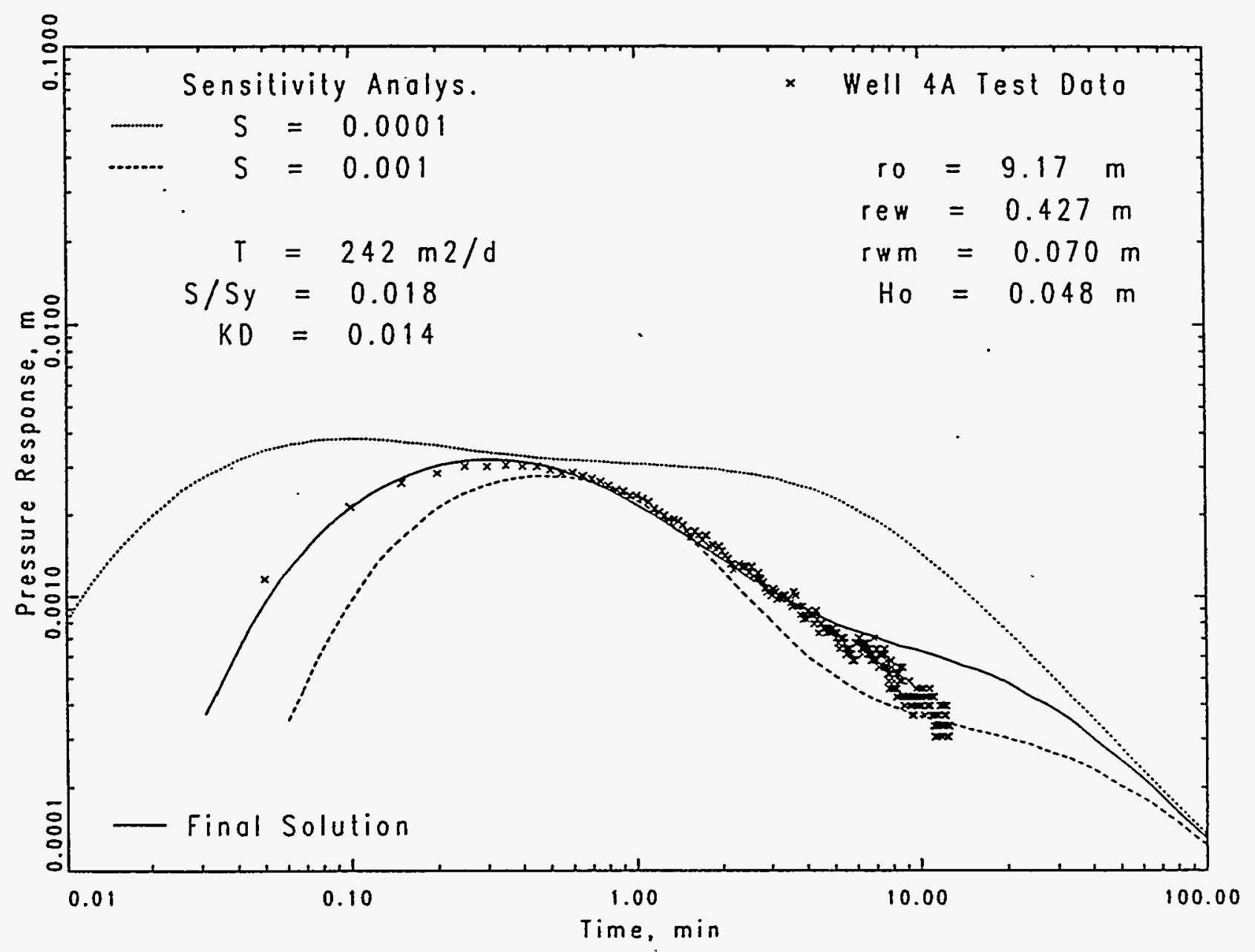


Figure 10. Sensitivity of Predicted S1ug Interference Response for We $114 \mathrm{~A}$ to Wellbore Storage Effects $\left(T=242 \mathrm{~m}^{2} / \mathrm{d}, \mathrm{S} / \mathrm{S}_{y}=0.018, K_{0}=0.14\right)$.

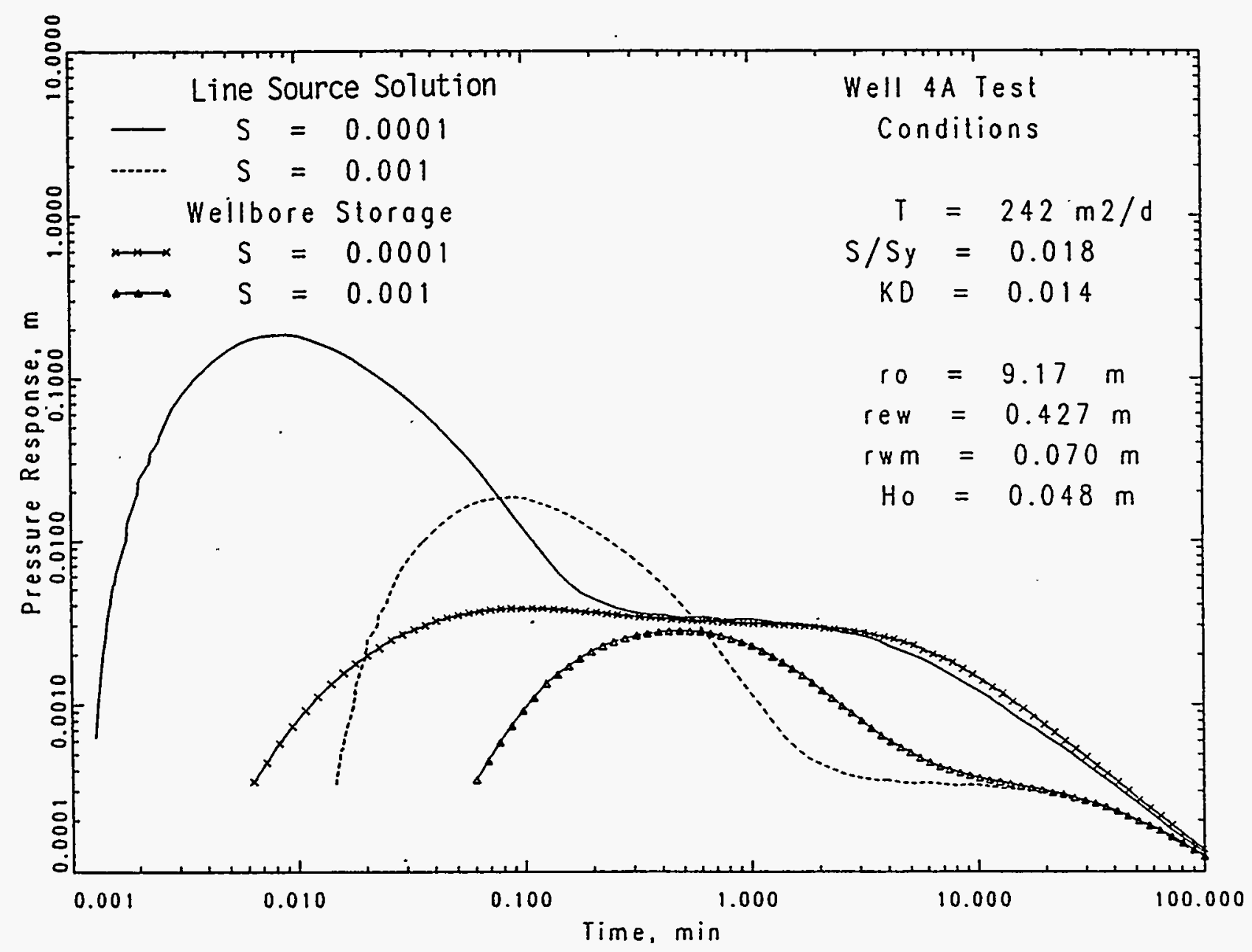


WHC-SD-EN-TI-260, Rev. 0

Figure 11. Sensitivity of Predicted Slug Interference Response for We11 4A to Varying $S / S_{y}\left(T=242 \mathrm{~m}^{2} / \mathrm{d}, S=0.0005, K_{D}=0.14\right)$.

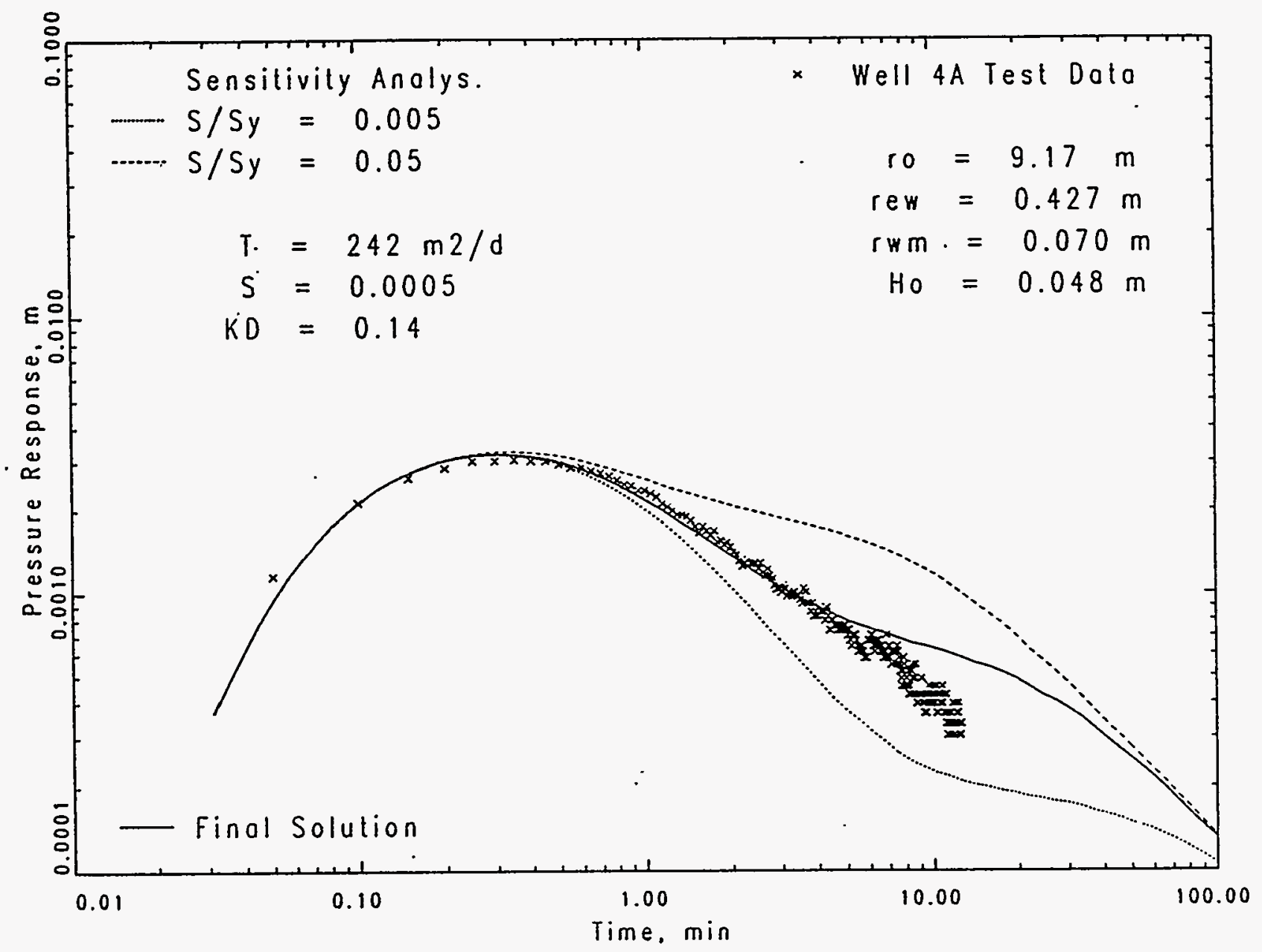


Figure 12. Sensitivity of Predicted Slug Interference Response for Well $4 \mathrm{~A}$ to Varying $K_{D}\left(T=242 \mathrm{~m}^{2} / \mathrm{d}, S=0.0005, S / S_{y}=0.018\right)$.

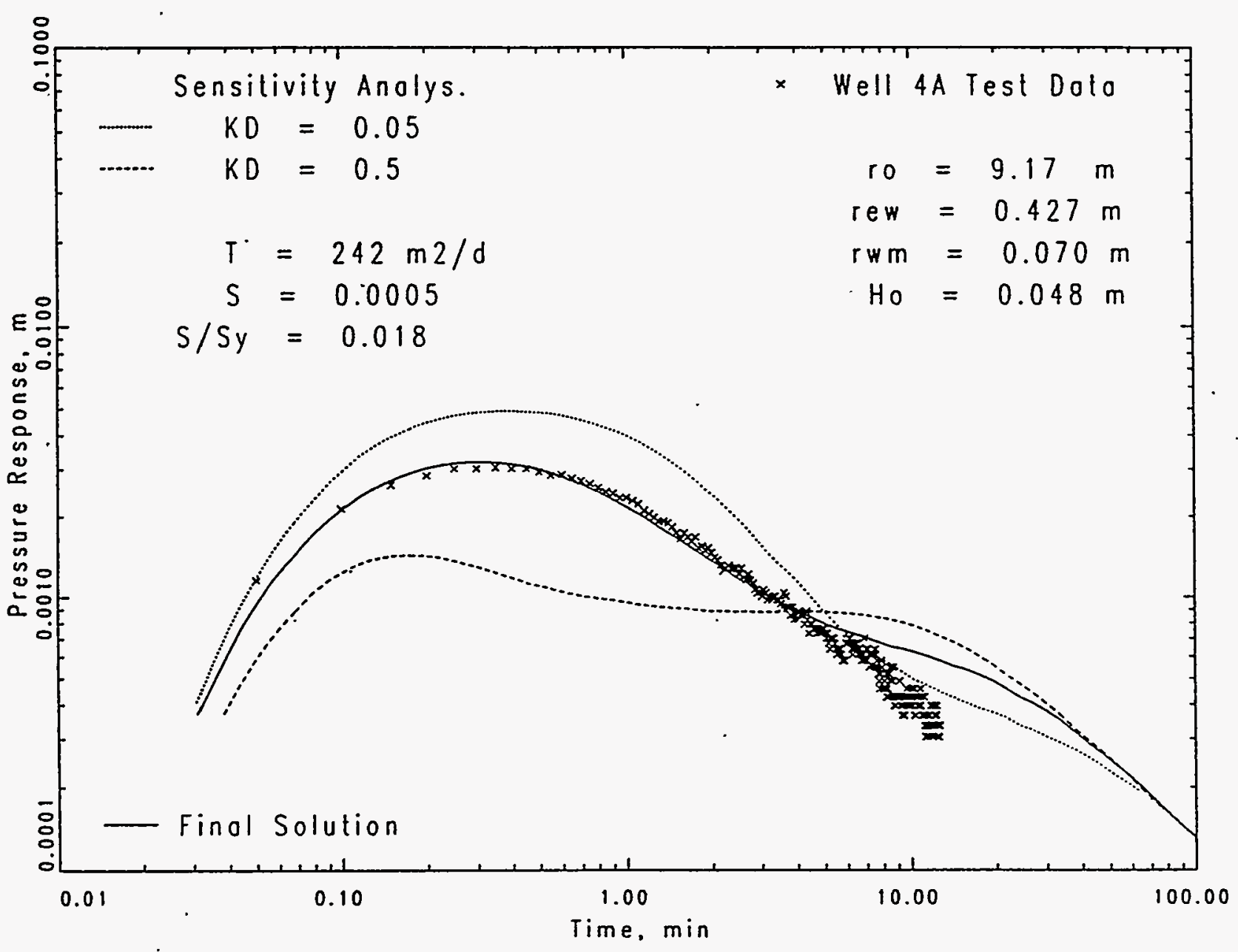


- The storativity/specific yield ratio affects primarily the slope of the recessional limb of the initial slug interference "hump" response (Figure 11).

- Vertical anisotropy, like storativity, exerts a significant influence on the amplitude and shape of the initial slug interference response (Figure 12); however, the predominant region of influence is the peak amplitude and recessional limb of the interference response.

\subsection{SUMMARY}

A general procedure is outlined for generation of slug interference test responses within anisotropic, unconfined aquifers with partially penetrating well configurations. The procedure is based on conversion of available unconfined aquifer constant-rate pumping test type curves, which have been modified to account for the affects of pumping well wellbore storage. Results of sensitivity analyses indicated that variations in $T, S, S_{y}, K_{0}$ exert significant influence (in varying degrees) on the transmission, amplitude, and shape of the slug interference response.

A comparison of hydraulic property estimates obtained from the reanalysis of the constant-rate pumping and slug interference tests (shown in Table 1) indicates a close correspondence. The close correspondence in hydraulic property estimates suggests that slug interference tests can provide similar characterization results, under favorable test conditions.

Table 1. Comparison of Hydraulic Test Analysis Results for Well 4A.

\begin{tabular}{|c|c|c|c|c|c|c|c|c|}
\hline \multirow[b]{2}{*}{ Test analysis } & \multicolumn{4}{|c|}{ Re-analysis results } & \multicolumn{4}{|c|}{ Previous analysis results ${ }^{a}$} \\
\hline & $m^{2} / d$ & S & $S_{y}$ & $K_{0}$ & $\mathrm{~m}^{2} / \mathrm{d}$ & $S$ & $S_{y}$ & $K_{D}$ \\
\hline $\begin{array}{l}\text { Constant-rate } \\
\text { pumping test }\end{array}$ & & & & & & & & \\
\hline $\begin{array}{l}\text { Type B curve } \\
\text { analysis }\end{array}$ & 254 & NA & 0.025 & 0.15 & NA & NA & NA & NA \\
\hline $\begin{array}{l}\text { Complete } \\
\text { unconfined } \\
\text { aquifer curve } \\
\text { analysis }\end{array}$ & 254 & 0.001 & 0.025 & 0.10 & 269 & 0.0045 & 0.016 & 0.11 \\
\hline $\begin{array}{l}\text { Slug inter- } \\
\text { ference test }\end{array}$ & 242 & 0.0005 & 0.028 & 0.14 & 763 & NA & 0.012 & NA \\
\hline
\end{tabular}

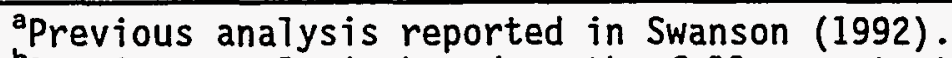

brevious analysis based on the fully penetrating confined aquifer solution method presented in Novakowski (1990); re-analysis based on the partial penetration unconfined aquifer solution method presented in this document.

$N A=$ not applicable. 


\subsection{REFERENCES}

Bourdet, D., T. M. Whittle, A. A. Douglas, and Y. M. Pirard, 1983, "A New Set of Type Curves Simplifies Hell Test Analysis," Horld 0il, May: 95-106.

Bourdet, D., J. A. Ayoub, and Y. M. Pirard, 1989, "Use of Pressure Derivative in We11-Test Interpretation," SPE Formation Evaluation, June 1989: 293-302.

Bouwer, H., 1989, "The Bouwer and Rice Slug Test - An Update," Ground Water, Vol. 27 , no. 3 .

Cooper, H. H., Jr., J. D. Bredehoeft, and I. S. PapadopuTos, 1967, "Response of a Finite-Diameter Well to an Instantaneous Charge of Hater, "Water Resources Research, 3(1):263-269.

Dawson, K. J. and J. D. Istok, 1991, Aquifer Testing: Design and Analysis of Pumping and Slug Tests, Lewis Publishers, Inc., Chelsea, Michigan.

Earlougher, R. C., Jr., 1977, Advances in Well Test Analysis, Henry L. Doherty Series, Monograph Volume 5, Soc. of Pet. Engineers, AIME.

Fenske, P. R., 1977, "Radial Flow with Discharging-We11 and Observation-Well Storage," Journal of Hydrology, 32:87-96.

Horn, R. N., 1990, Modern Well Test Analysis: A Computer-Aided Approach, Petroway, Inc., Palo Alto, California; distributed by Soc. Pet. Engrs., Richfield, Texas.

HydraLogic, 1989, ISOAQX: Operations Guide, Hydralogic, Missoula, Montana.

Moench, A. F., 1993, "Computation of Type Curves for Flow to Partially Penetrating Wells in Water-Table Aquifers," Ground Water, 31(6):966-971.

Neuman, S. P., 1975, "Analys is of Pumping Test Data from Anisotropic Unconfined Aquifers Considering Delayed Gravity Response, "Water Resources Research, 11(2):329-342.

Novakowski, K. S., 1989, "Analys is of Pulse Interference Tests," Hater Resources Research, 25(11):2377-2387.

Novakowski, K. S., 1990, "Analysis of Aquifer Tests Conducted in Fractured Rock: A Review of the Physical Background and the Design of a Computer Program for Generating Type Curves," Ground Water, 28(1):99-105.

Peres, A. M., 1989, "Analysis of Slug and Drillstem Tests," unpublished Ph.D. dissertation, University of Tulsa, Tulsa, Oklahoma.

Peres, A. M., M. Onur, and A. C. Reynolds, 1989, "A New Analys is Procedure For Determining Aquifer Properties from Slug Test Data," Water Resources Research, 25(7):1591-1602. 
Reed, J. E., 1980, "Type Curves for Selected Problems of Flow to Wells in Confined Aquifers," in Techniques of Water-Resources Investigations, Book 3, Chapter B3, U.S. Geological Survey.

Spane, F. A., Jr., 1992, Applicability of Slug Interference Tests Under Hanford Site Test Conditions: Analytical Assessment and Field Test Evaluation, PNL-8070, Pacific Northwest Laboratory, Richland, Washington.

Spane, F. A., Jr., 1993, Selected Hydraulic Test Analysis Techniques for Constant-Rate Discharge Tests, PNL-8539, Pacific Northwest Laboratory, Richland, Washington.

Spane, F. A., Jr., and S. K. Wurstner, 1993, "DERIV: A Program for Calculating Pressure Derivatives for Use in Hydraulic Test Analysis," Ground Water, 31(5):814-822; also as PNL-SA-21569, Pacific Northwest Laboratory, Richland, Washington.

Swanson, L. C., 1992, Phase 1 Hydrogeologic Summary of the 300-FF-5 Operable Unit, 300 Area, WHC-SD-EN-TI-052, Rev. 0, Westinghouse Hanford Company, Richland, Washington. 